\title{
Efficacy, tolerability and safety of biologic therapy in rheumatoid disease: patient considerations
}

\author{
This article was published in the following Dove Press journal: \\ Drug, Healthcare and Patient Safety \\ 16 August 2010 \\ Number of times this article has been viewed
}

\section{Sarah Horton' \\ Maya $\mathrm{H} \mathrm{Buch}^{2}$ \\ Paul Emery ${ }^{2}$}

'Section of Musculoskeletal Disease, Leeds Institute of Molecular Medicine, University of Leeds, ${ }^{2} \mathrm{NIHR}$ Leeds Musculoskeletal Biomedical Research Unit, Leeds Teaching Hospitals NHS Trust, Leeds, UK
Correspondence: Paul Emery

Academic Unit of Musculoskeletal

Disease, Second Floor, Chapel Allerton

Hospital, Chapeltown Road, Leeds,

LS7 4SA, UK

Tel +44 II 33924884

Fax +44 II 3392499 |

Email p.emery@leeds.ac.uk

\begin{abstract}
Rheumatoid arthritis (RA) is a systemic inflammatory disease in which chronic inflammation leads to joint destruction and extra-articular complications. Early and effective inhibition of inflammation is critical in order to prevent the progressive joint damage that occurs rapidly after onset of the disease. In the past, treatment for this purpose was limited to conventional disease-modifying antirheumatic drugs (DMARDs), which were often suboptimal. Within the last decade however, the development of biologic therapies, targeted against cytokines and cells involved in the inflammatory process, has revolutionized the management of RA. Disease remission is now an achievable goal in newly diagnosed patients. Since the advent of the first tumor necrosis factor- $\alpha$ inhibitor in 1999, other biologics have proved necessary as individuals respond to varying degrees with different therapies. Several are now available for the treatment of patients with RA that remains active despite DMARD treatment. This article reviews the evidence, over the last decade, of the efficacy and safety of biologic therapies used in this context, and the recent clinical data supporting the use of biologic therapy earlier in the disease process as first-line therapy.
\end{abstract}

Keywords: rheumatoid arthritis, biologic therapy, tumor necrosis factor, abatacept, rituximab, tocilizumab, safety

\section{Introduction}

Rheumatoid arthritis (RA) is a chronic inflammatory disease affecting $1 \%$ of adult Western populations, and is the largest cause of treatable disability in the Western World. ${ }^{1}$ It is associated with considerable pain, stiffness, and swelling of joints. If not adequately controlled, it results in joint destruction, deformity, and disability. In addition, it is a systemic disorder; persistent systemic inflammation may lead to extra-articular manifestations, and also to increased cardiovascular morbidity and mortality. $^{2}$

The socio-economic impact is also significant. A study in 1989 demonstrated that, 10 years after diagnosis of RA, only half of patients were employed and $42 \%$ of patients considered themselves disabled. ${ }^{3}$ Since then, improved understanding of the disease has shaped clinical practice, with the current approach to treatment being based principally upon the paradigm that the level of inflammation over time determines damage. Studies have demonstrated that damage occurs early in the disease process, and that subclinical inflammation and associated joint damage can continue despite improvement in patients' symptoms with treatment. ${ }^{4}$ Hence, the aim of treatment of RA has advanced from symptom control to early and optimal control of inflammation, with use of immunosuppressive disease-modifying antirheumatic drugs (DMARDs) such as methotrexate (MTX). 
Comparison of treatment strategies in early RA has confirmed that tight control of inflammatory disease activity offers improved outcomes for patients. The TICORA study compared routine treatment (DMARD treatment and three-monthly assessment) to intensive management involving monthly assessment and escalation of DMARD treatment in the presence of even low-level disease activity, according to a protocol. ${ }^{5}$ A similar comparison of three-monthly versus monthly assessment was employed in the CAMERA study, in which treatment with MTX was increased, or another DMARD was added as necessary to meet targets of disease control. ${ }^{6}$

For a number of patients however, MTX and other conventional DMARDs are ineffective at achieving suppression of disease activity and preventing permanent joint damage. This need for alternative, superior treatment options has led to the development of biologic therapies, targeted against cells and cytokines known to play a role in the pathogenesis of RA (Figure 1). ${ }^{7}$ In clinical practice, biologic therapies are licensed for use in patients with moderate to severely active RA who have not responded to DMARDs. This article reviews the evidence supporting their use in these circumstances and the emerging evidence for use outside this remit in patients with early RA who may not have previously received DMARD treatment.

\section{Assessing efficacy of biologics}

International standards for assessment of disease activity in RA allow comparison of response to treatment across studies (Table 1). When a number of outcome measures of disease activity were assessed using expert opinion and analysis of placebo-controlled trial data, 20\% improvement in the American College of Rheumatology response criteria (ACR20) proved reliable at discriminating active treatments from placebo effects. ${ }^{8}$ This is commonly used as the primary outcome measure in randomized controlled trials of RA treatment, including many of the trials discussed in this review. However, it is of no use for measuring the status of disease activity in the individual patient in clinic, unlike the Disease Activity Score (DAS), a continuous variable that relates to disease state and is useful in clinical practice.

\section{TNF inhibition}

The first inhibitor of the cytokine tumor necrosis factor- $\alpha$ (TNF- $\alpha$ ), infliximab, was launched over 10 years ago, initially for use in Crohn's disease. Since then, infliximab and others have been approved for use in rheumatoid disease. Infliximab, adalimumab, and etanercept are blockers of TNF that have been used in clinical practice for several years, while certolizumab and golimumab have recently been developed and approved (Table 2). Clinical trials demonstrating their efficacy are discussed below.

\section{Infliximab}

An initial dose-ranging study of infliximab demonstrated reduced immunogenicity and better efficacy when administered with MTX, ${ }^{30}$ and it was licensed for use with

\begin{tabular}{|c|c|c|}
\hline \multicolumn{2}{|c|}{$\begin{array}{c}\text { Cell surface proteins on } \\
\text { lymphocytes }\end{array}$} \\
\hline & & \\
& &
\end{tabular}

Figure I Targets of current biological therapies for RA.

Note: *Developed and assessed in clinical trials, but not yet widely available.

Abbreviations: CTLA 4, cytotoxic T-lymphocyte antigen 4; $C D$, cluster of differentiation. 
Table I Outcome measures used in intervention studies in RA

\begin{tabular}{|c|c|}
\hline Outcome measure & Method of assessment \\
\hline \multicolumn{2}{|l|}{ Composite measures of disease activity: } \\
\hline $\begin{array}{l}\text { American College of Rheumatology (ACR) response } \\
\text { criteria: }\end{array}$ & $\begin{array}{l}\text { A } 20 \%, 50 \% \text { or } 70 \% \text { improvement in the following measures } \\
\text { of disease: }\end{array}$ \\
\hline - ACR20 & - number of tender joints \\
\hline - ACR50 & - number of swollen joints \\
\hline - ACR70 & $\begin{array}{l}\text { - at least three out five further criteria: patient's assessment of pain, global health, or } \\
\text { physical function; physician assessment of global health or a laboratory marker of } \\
\text { inflammation (CRP or ESR). }{ }^{8}\end{array}$ \\
\hline \multirow[t]{7}{*}{ Disease activity score (DAS) } & Calculated using a mathematical formula comprising: \\
\hline & - number of swollen joints (out of 28 specified joints in the case of DAS28) \\
\hline & • number of tender joints (out of 28 ) \\
\hline & - patient self-assessment of global health (on a visual analog scale) \\
\hline & - laboratory markers (CRP or ESR) \\
\hline & A DAS28 score of 5.1 or more is classed as high disease activity; low disease activity is \\
\hline & 3.2 or less, and clinical remission is less than 2.6 . \\
\hline \multicolumn{2}{|l|}{ Patient outcomes: } \\
\hline $\begin{array}{l}\text { Health-related quality of life, } \\
\text { Short form-36 (SF-36) }\end{array}$ & $\begin{array}{l}\text { A self-assessment questionnaire measuring eight aspects of mental and physical well-being, } \\
\text { summarized in the mental component summary (MCS) and physical component summary } \\
\text { (PCS), judged on a scale of } 0 \text { to } 100 \text {, where } 0 \text { is the worst and } 100 \text { is the best outcome. } \\
\text { The minimal improvement which is accepted as meaningful is a decrease of at least } \\
3 \text { units. }\end{array}$ \\
\hline \multirow[t]{2}{*}{$\begin{array}{l}\text { Health assessment questionnaire disability index } \\
\text { (HAQ-DI) }\end{array}$} & $\begin{array}{l}\text { A self-assessment questionnaire of } 8 \text { aspects of physical disability, giving a score of } 0 \text { to } 3 \text {, } \\
\text { where } 0 \text { is no disability and } 3 \text { is completely disabled. }\end{array}$ \\
\hline & The minimal improvement which is accepted as meaningful is a decrease of 0.22 or more. ${ }^{9}$ \\
\hline \multicolumn{2}{|l|}{ Radiological outcomes: } \\
\hline $\begin{array}{l}\text { Sharp score } \\
\text { (and modifications of it) }\end{array}$ & $\begin{array}{l}\text { Grading of the radiographic appearance of joints according to the degree of narrowing } \\
\text { of the joint space and the severity of bone erosions. } .^{10}\end{array}$ \\
\hline
\end{tabular}

Abbreviations: CRP, C-reactive protein; ESR, erythrocyte sedimentation rate.

MTX in 1999. The ATTRACT study went on to assess the efficacy of infliximab with MTX in patients who had active RA despite at least three months of treatment with MTX. ${ }^{11}$ Patients were randomized to placebo or one of four treatment regimens: infliximab $3 \mathrm{mg} / \mathrm{kg}$ every 4 or 8 weeks and $10 \mathrm{mg} / \mathrm{kg}$ every 4 or 8 weeks. Disease duration ranged between 0.5 and 49.9 years, but was matched across treatment groups, with the median duration being 7.2-9.0 years across the groups. At 30 weeks, superior clinical response, assessed by the proportion of patients achieving ACR20 and ACR50, was seen in all groups receiving infliximab compared to placebo (Table 3). The study was continued to 54 weeks. Response with infliximab plus MTX was sustained, and superiority to placebo plus MTX remained significant. ${ }^{12}$ As efficacy was comparable between infliximab groups but side-effects were more frequent with higher doses, $3 \mathrm{mg} / \mathrm{kg}$ was chosen as the licensed dose. After this year, treatment was unblinded and patients could continue their allocated treatment over a further one year. ${ }^{31}$ Lower numbers of patients in the placebo group ( 28 compared to 55-64 in the infliximab plus
MTX groups) may be accounted for by their high rate of withdrawal due to lack of efficacy in the first year (36\%). Again, clinical response was maintained, as illustrated by similar ACR20, ACR50 and ACR70 responses.

Progression in joint damage at one year was compared between groups using the mean change in the total modified Sharp score from baseline. The mean change in total score in the MTX controls was 7.0, compared to a mean change ranging from -0.7 to 1.6 in infliximab-treated groups $(P<0.001)$, with the mean improvement of 0.7 seen in patients receiving the highest dose of infliximab. ${ }^{12}$ Even in patients who did not clinically respond to treatment (ie, did not meet ACR20 criteria), infliximab had a beneficial effect on radiographic progression; mean change in total score in the MTX nonresponders was 7.2 compared to a mean of 0.2-2.6 in infliximab nonresponders $(P \leq 0.002)$. In a sub-analysis of patients with early disease (less than three years disease duration), even greater differences were seen with the addition of infliximab. ${ }^{32}$ Mean changes in total score were 9.1 in MTX controls compared to -1.1 to 0.6 with infliximab and MTX. 
Table 2 TNF inhibitors used in RA

\begin{tabular}{|c|c|c|c|}
\hline TNF inhibitor & Molecular structure & Administration & $\begin{array}{l}\text { Randomized controlled } \\
\text { trials (double-blind, } \\
\text { unless otherwise stated) }\end{array}$ \\
\hline & & $\begin{array}{l}\text { - Dose } \\
\text { - Route } \\
\text { - Frequency }\end{array}$ & \\
\hline Infliximab & $\begin{array}{l}\text { Chimeric monoclonal } \\
\text { antibody to TNF; human and } \\
\text { mouse components. }\end{array}$ & $\begin{array}{l}\text { - } 3 \text { or } 5 \mathrm{mg} / \mathrm{kg} \\
\text { - Intravenous } \\
\text { - At } 0,2 \text {, and } 6 \text { weeks } \\
\text { then every } 2 \text { months } \\
\text { - Concomitant MTX is } \\
\text { necessary to decrease } \\
\text { immunogenicity. }\end{array}$ & $\begin{array}{l}\text { ATTRACT }{ }^{11,12} \\
\text { Early RA and MTX-naïve: } \\
\text { ASPIRE }^{13} \\
\text { Early RA: } \\
\text { BeSt }^{14} \text { (single-blind) }\end{array}$ \\
\hline Adalimumab & Fully human monoclonal antibody to TNF. & $\begin{array}{l}\text { - } 40 \mathrm{mg} \\
\text { - Subcutaneous } \\
\text { - Every } 2 \text { weeks }\end{array}$ & $\begin{array}{l}\text { ARMADA }{ }^{15} \\
\text { van der Putte et } \text { al }^{16} \\
\text { Early RA and MTX-naïve: } \\
\text { PREMIER }^{17} \\
\text { PROWD }^{18}\end{array}$ \\
\hline Etanercept & $\begin{array}{l}\text { Fusion protein of the soluble TNF receptor, } \\
\text { linked to the constant fragment }(\mathrm{Fc}) \text { of } \\
\text { immunoglobulin. }\end{array}$ & $\begin{array}{l}\text { - } 50 \text { mg } \\
\text { - Subcutaneous } \\
\text { - Every week } \\
\text { (or } 25 \mathrm{mg} \\
\text { twice weekly) }\end{array}$ & 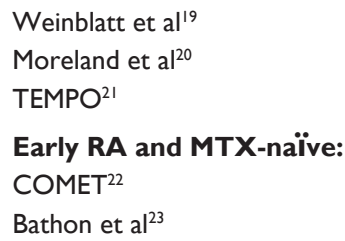 \\
\hline Certolizumab & $\begin{array}{l}\text { Antigen-binding fragment (Fab) of human } \\
\text { anti-TNF antibody bound to polyethylene } \\
\text { glycol, as opposed to the Fc fragment present } \\
\text { in other monoclonal antibodies and anti-TNF } \\
\text { drugs. Developed with lack of the Fc fragment, } \\
\text { with the intention of increasing its half-life and } \\
\text { reducing immunogenicity. }\end{array}$ & $\begin{array}{l}\text { - } 400 \mathrm{mg} \\
\text { - Subcutaneous } \\
\text { - At } 0,2 \text {, and } 4 \text { weeks } \\
\text { then every } 4 \text { weeks } \\
\text { (or } 200 \mathrm{mg} \text { every } \\
2 \text { weeks) }\end{array}$ & $\begin{array}{l}\text { RAPID } 1^{24} \\
\text { RAPID } 2^{25} \\
\text { FAST4WARD } 26\end{array}$ \\
\hline Golimumab & $\begin{array}{l}\text { Fully human monoclonal } \\
\text { antibody to TNF. }\end{array}$ & $\begin{array}{l}\text { - } 50 \mathrm{mg} \\
\text { - Subcutaneous } \\
\text { - Every } 4 \text { weeks }\end{array}$ & $\begin{array}{l}\text { GO-FORWARD }{ }^{27} \\
\text { Early RA and MTX-naïve: } \\
\text { GO-BEFORE }{ }^{28} \\
\text { Previous Anti-TNF } \\
\text { Treatment: } \\
\text { GO-AFTER }^{29}\end{array}$ \\
\hline
\end{tabular}

The ASPIRE study similarly compared MTX alone to combination with infliximab, but included only patients with RA of less than three years duration who were MTXnaïve. ${ }^{13}$ The majority of patients had not had prior exposure to any DMARDs. As expected, compared to the ATTRACT study of MTX-resistant patients, higher ACR response rates were seen across all treatment groups (Table 3). Despite the higher response rates in this study with MTX alone, significantly higher proportions of patients on infliximab in combination with MTX achieved the superior response levels (ACR50 and ACR70). The addition of infliximab also significantly decreased the progression of joint damage, assessed using the modified Sharp score; from the median increase of 0.4 with MTX alone to a median change of 0.0 seen in infliximab treatment groups $(P<0.001)$.
The BeSt study compared four treatment strategies in early RA: MTX alone, changing to alternative DMARDs if response inadequate; MTX alone, adding other DMARDs in combination if response inadequate; combination DMARD therapy initially with high-dose corticosteroids; and MTX with the biologic agent infliximab initially. ${ }^{14}$ More rapid clinical improvement was achieved when a combination of DMARDs or MTX with infliximab was used as a first line, with less progression of joint damage seen on radiographs. In cases where disease remained effectively suppressed, drug therapies (preferentially corticosteroids or infliximab in the first instance) were tapered and withdrawn. This was most successful in the group initially treated with infliximab combination therapy; $53 \%$ of patients were on just one drug for disease control at the end of the twoyear study (compared to $31 \%-36 \%$ in other groups). ${ }^{14}$ 
Table 3 The proportion of RA patients achieving the levels of clinical improvement defined by the ACR (American College of Rheumatology) response criteria with combination infliximab and methotrexate compared to methotrexate alone

\begin{tabular}{|c|c|c|c|c|c|c|c|c|}
\hline & \multicolumn{5}{|c|}{ ATTRACT ${ }^{11,12}$} & \multicolumn{3}{|c|}{ ASPIRE $^{13}$} \\
\hline & $\begin{array}{l}\text { MTX + } \\
\text { placebo } \\
\mathbf{n}=\mathbf{8 8}\end{array}$ & $\begin{array}{l}\text { MTX + INF } \\
3 \mathrm{mg} / \mathrm{kg} \\
8 \mathrm{wkly} \\
\mathrm{n}=86\end{array}$ & $\begin{array}{l}\text { MTX + INF } \\
3 \mathrm{mg} / \mathrm{kg} \\
4 \mathrm{wkly} \\
\mathrm{n}=86\end{array}$ & $\begin{array}{l}\text { MTX + INF } \\
10 \mathrm{mg} / \mathrm{kg} \\
8 \mathrm{wkly} \\
\mathrm{n}=87\end{array}$ & $\begin{array}{l}\text { MTX + INF } \\
10 \mathrm{mg} / \mathrm{kg} \\
4 \mathrm{wkly} \\
\mathrm{n}=8 \mathrm{I}\end{array}$ & $\begin{array}{l}\text { MTX + } \\
\text { placebo } \\
n=298\end{array}$ & $\begin{array}{l}\text { MTX + INF } \\
3 \mathrm{mg} / \mathrm{kg} \\
8 \mathrm{wkly} \\
\mathrm{n}=373\end{array}$ & $\begin{array}{l}\text { MTX + INF } \\
6 \mathrm{mg} / \mathrm{kg} \\
8 \mathrm{wkly} \\
\mathrm{n}=378\end{array}$ \\
\hline \multicolumn{9}{|c|}{ At 30 wks (\%): } \\
\hline ACR 20 & 20 & $50^{\mathrm{a}}$ & $53^{a}$ & $52^{\mathrm{a}}$ & $58^{a}$ & & & \\
\hline ACR 50 & 5 & $27^{a}$ & $29^{a}$ & $31^{a}$ & $26^{a}$ & & & \\
\hline ACR 70 & 0 & 8 & II & $18^{\mathrm{a}}$ & II & & & \\
\hline \multicolumn{9}{|c|}{ At 54 wks (\%): } \\
\hline ACR 20 & 17 & $42^{\mathrm{a}}$ & $48^{\mathrm{a}}$ & $59^{a}$ & $59^{a}$ & 54 & 62 & 66 \\
\hline ACR 50 & 8 & 21 & $34^{a}$ & $39^{a}$ & $38^{\mathrm{a}}$ & 32 & $46^{a}$ & $50^{a}$ \\
\hline ACR 70 & 2 & 10 & 17 & $25^{\mathrm{a}}$ & $19^{a}$ & 21 & 33 & $37^{a}$ \\
\hline
\end{tabular}

Note: ${ }^{a} P<0.00$ I compared to placebo.

Abbreviations: ACR20, ACR50, ACR70, American College of Rheumatology response criteria improvements of $20 \%$, 50\%, and 70\%; MTX, methotrexate; INF, infliximab.

Quinn et al attempted to induce clinical remission in very early RA (DMARD-naïve patients with less than one year of symptoms) in a small number of patients with poor prognostic features of disease such as positive rheumatoid factor. ${ }^{33}$ Twenty patients were treated with MTX and randomly assigned to receive either placebo or infliximab for one year. The primary outcome of the study was achieved (a difference between the groups in reduction of synovitis on magnetic resonance imaging at 14 weeks). Improvement in disease control, assessed by DAS28, was more rapid in the infliximab group; at 14 weeks, median DAS28 was significantly lower compared with the placebo group. But at 2 years (one year after stopping infliximab), although median DAS28 was lower in infliximab-treated patients and within the remission range, there was no significant difference compared to placebo. There was a significant difference between the groups at 2 years however: in physical function, assessed by the Health Assessment Questionnaire (HAQ) score $(P<0.05)$. The authors postulate that this may be due to the faster control of disease activity, that rapid disease control may have socioeconomic benefits, and prevent adverse illness behavior later in the disease. Follow-up data suggests that early biologic treatment in patients with poor prognostic features may have consequences for long-term disease control; at 8 years, $40 \%$ of the patients initially treated with infliximab were still in remission, compared to $0 \%$ of controls. ${ }^{34}$

\section{Adalimumab}

Results of the ARMADA trial were published in 2003, showing the efficacy of adalimumab in combination with MTX. ${ }^{15}$ Similar to the ATTRACT study for infliximab, patients had a range of disease duration (on average approximately 12 years) and had active disease despite at least 6 months of MTX treatment. At 24 weeks, at a dose of $40 \mathrm{mg}$ every two weeks (the dose used in current clinical practice), patients had significantly greater clinical responses at ACR20, ACR50, and ACR 70 levels (Table 4). Patients reported greater improvement in physical function as assessed by the 0-3 scale of the HAQ score; mean improvement of 0.62 with adalimumab and MTX, compared to 0.27 with MTX alone $(P<0.001)$. Long-term efficacy data is available after a 4-year open-label extension study in which all patients received adalimumab in combination with MTX. ${ }^{35}$ The proportion of patients still receiving adalimumab at 4 years was $62 \%$; adalimumab was stopped in $8 \%$ of patients due to lack of efficacy. Comparison between data at 6 months and 4 years, for patients in the original adalimumab treatment groups who continued on treatment, showed that clinical response with adalimumab treatment was maintained.

Keystone et al assessed the effect of adalimumab plus MTX on radiographic progression over one year in a randomized controlled trial of MTX nonresponders. ${ }^{36}$ Patients treated with adalimumab and MTX had a smaller mean change in modified total Sharp score compared to patients on MTX and placebo (0.1 vs 2.7; $P<0.001)$.

Unlike infliximab, adalimumab has been shown to be safe and effective when used as monotherapy. This was confirmed by van der Putte et al in patients who had, on average, a disease duration of 11 years, and had failed previous DMARD treatment (the majority of patients had failed at least three different DMARDs). ${ }^{16}$ The proportion of patients achieving an ACR20 response was significantly higher in the adalimumab group compared to the placebo group (46\% vs 19\%; 
Table 4 The proportion of RA patients achieving the levels of clinical improvement defined by the ACR (American College of Rheumatology) response criteria with combination adalimumab and methotrexate (ARMADA) ${ }^{15}$ and adalimumab monotherapy (van der Putte) ${ }^{16}$

\begin{tabular}{|c|c|c|c|}
\hline \multicolumn{2}{|c|}{ ARMADA $^{15}$} & \multicolumn{2}{|c|}{ van der Putte et al $^{16}$} \\
\hline $\begin{array}{l}\text { MTX + } \\
\text { placebo } \\
n=67\end{array}$ & $\begin{array}{l}\text { MTX + } \\
\text { adalimumab } \\
40 \mathrm{mg} \\
2 \text { weekly } \\
\mathrm{n}=62\end{array}$ & $\begin{array}{l}\text { Placebo } \\
n=1 \mid 3\end{array}$ & $\begin{array}{l}\text { Adalimumab } \\
40 \mathrm{mg} \\
2 \text { weekly } \\
\mathrm{n}=110\end{array}$ \\
\hline
\end{tabular}

\section{At 24-26 wks}

(\%):

\begin{tabular}{lllll} 
ACR 20 & 15 & $67^{\mathrm{a}}$ & 19 & $46^{\mathrm{a}}$ \\
ACR 50 & 8 & $55^{\mathrm{a}}$ & 8 & 22 \\
ACR 70 & 5 & $27^{\mathrm{a}}$ & 2 & 12 \\
\hline
\end{tabular}

Note: ${ }^{a}<<0.001$ compared to placebo.

Abbreviations: ACR20, ACR50, ACR70, American College of Rheumatology response criteria improvements of $20 \%, 50 \%$, and $70 \%$; MTX, methotrexate.

$P<0.001)$. This has importance for patients who are unable to take MTX, either because of intolerance to its side-effects or due to a contraindication. However, as superior efficacy is achieved with combination treatment, MTX should be used when possible.

The PREMIER study investigated patients with early RA (disease duration up to 3 years) and poor prognostic disease (rheumatoid factor positive or at least 1 joint erosion). ${ }^{17}$ Patients were excluded if they had received specified DMARDs including MTX. Patients were randomized to receive adalimumab in combination with MTX, adalimumab monotherapy, or MTX monotherapy. Of patients in the combination therapy arm, $62 \%$ achieved the primary endpoint of an ACR50 response, which was significantly greater in comparison to adalimumab monotherapy (46\%) and MTX monotherapy (41\%) $(P<0.001$ for both comparisons). The rate of remission (DAS28<2.6) at 2 years was $49 \%$ in patients on combination therapy, twice that seen in the other treatment arms. At 2 years, the mean change in modified total Sharp score with the combination treatment was 1.9 compared to 10.4 with MTX alone $(P<0.001)$; and HAQ Disability Index (DI) improved by the minimal clinically meaningful difference in $72 \%$ of patients on combination therapy compared to $58 \%$ and $63 \%$ in adalimumab and MTX monotherapy groups respectively $(P<0.05)$. Further analysis to determine the relationship between radiographic progression and clinical response demonstrated that significantly less radiographic progression was achieved in patients on combination therapy compared to MTX monotherapy across all clinical outcomes, including patients who showed poor clinical response (patients not meeting the ACR20 response criteria). ${ }^{37}$
In a sub-analysis of patients in the PREMIER study, effect on quality of life was assessed, using the SF-36 health survey, and compared to a sample of the general United States population (from a national survey in 1998). ${ }^{38}$ As expected, baseline scores for the physical component summary (PCS) and mental component summary (MCS) were higher in the US population compared to the RA group. At 2 years, the PCS for those receiving combination therapy increased to a level similar to that of the general population (47.8 vs 49.4; $P=0.08)$. For those receiving MTX monotherapy, the score increased but remained significantly lower than the general population (44.4 vs $49.4 ; P<0.0001$ ). This is impressive, considering that these were patients selected on the basis of indicators of poor prognosis.

In the PROWD study, MTX-naïve patients with early RA (duration up to 2 years) who had self-reported work impairment were randomized to adalimumab and MTX, or placebo and MTX. ${ }^{18}$ There was no difference in the primary outcome (job loss from any cause and/or imminent job loss after week 16): 16\% of patients on adalimumab and MTX compared to $27 \%$ of patients on MTX monotherapy $(P=0.092)$. There was a statistical difference however, if numbers over the full 56-week study period were taken: $19 \%$ compared to $40 \%$ respectively $(P=0.005)$. The authors point out that this may be due to the fact that more patients in the placebo group dropped out after week 16 (25 patients) compared to the adalimumab-treated group (15 patients).

\section{Etanercept}

Two randomized controlled trials published in 1999 showed the efficacy of etanercept. One study demonstrated the efficacy of etanercept in combination with MTX, ${ }^{19}$ and the other etanercept monotherapy. ${ }^{20}$ ACR20 was achieved in $71 \%$ of patients on etanercept and MTX combination therapy compared to $27 \%$ of controls $(P<0.001)$, and in $59 \%$ on etanercept monotherapy compared to $11 \%$ of controls $(P<0.001)$ (Table 5$)$. Study subjects were similar: mean disease durations were 13 years and 12 years respectively, and both studies required nonresponse to previous DMARDs (MTX in the study by Weinblatt et al and one out of four specified DMARDs, including MTX, in the study by Moreland et al). ${ }^{19,20}$

The TEMPO trial went on to compare three treatment groups in a double-blind controlled design: etanercept and MTX in combination, etanercept monotherapy, and MTX monotherapy. ${ }^{21}$ Patients also had established RA, but mean disease duration was lower (6.8 years), and they were required to have had lack of response to DMARD therapy but not 
Table 5 The proportion of RA patients achieving the levels of clinical improvement defined by the ACR (American College of Rheumatology) response criteria with combination etanercept and methotrexate and etanercept monotherapy

\begin{tabular}{|c|c|c|c|c|c|c|c|}
\hline & \multicolumn{2}{|c|}{ Weinblatt et al ${ }^{19}$} & \multicolumn{2}{|c|}{ Moreland et $\mathrm{al}^{20}$} & \multicolumn{3}{|c|}{ TEMPO $^{21}$} \\
\hline & $\begin{array}{l}\text { MTX + } \\
\text { placebo } \\
n=30\end{array}$ & $\begin{array}{l}\text { MTX + } \\
\text { etanercept } \\
25 \mathrm{mg} \\
\text { twice weekly } \\
\mathrm{n}=59\end{array}$ & $\begin{array}{l}\text { Placebo } \\
n=80\end{array}$ & $\begin{array}{l}\text { Etanercept } \\
25 \mathrm{mg} \\
\text { twice weekly } \\
\mathrm{n}=\mathbf{7 8}\end{array}$ & $\begin{array}{l}\text { MTX + } \\
\text { placebo } \\
n=228\end{array}$ & $\begin{array}{l}\text { Etanercept } \\
25 \mathrm{mg} \\
\text { twice weekly } \\
\mathrm{n}=223\end{array}$ & $\begin{array}{l}\text { MTX + } \\
\text { etanercept } \\
25 \mathrm{mg} \\
\text { twice weekly } \\
\mathrm{n}=23 \mathrm{I}\end{array}$ \\
\hline \multicolumn{8}{|c|}{ At 24-26 wks (\%): } \\
\hline ACR 20 & 27 & $7 I^{\mathrm{a}}$ & 11 & $59^{a}$ & & & \\
\hline ACR 50 & 3 & $39^{a}$ & 5 & $40^{a}$ & & & \\
\hline ACR 70 & 0 & 15 & I & 15 & & & \\
\hline \multicolumn{8}{|c|}{ At 52 wks (\%): } \\
\hline ACR 20 & & & & & 75 & 76 & 85 \\
\hline ACR 50 & & & & & 43 & 48 & $69^{a}$ \\
\hline ACR 70 & & & & & 19 & 24 & $43^{a}$ \\
\hline
\end{tabular}

Note: ${ }^{a} P<0.001$ compared to placebo.

Abbreviations: ACR20, ACR50, ACR70, American College of Rheumatology response criteria improvements of $20 \%, 50 \%$, and $70 \%$; $M$ TX, methotrexate.

MTX. This explains the higher response rates seen in the MTX group. In this patient cohort, a significantly better clinical response rate over MTX monotherapy was seen with etanercept and MTX at ACR50 and ACR70 levels, but no significant difference was seen with etanercept monotherapy (Table 5). However, radiographic progression was significantly less; at 1 year the mean change in total Sharp score for etanercept in combination with MTX, etanercept monotherapy, and MTX monotherapy was $-0.54,0.52$, and 2.80 respectively $(P<0.0001$ for combination therapy vs MTX, and $P=0.0469$ for etanercept monotherapy vs MTX). Improvement in patients' self-reported physical functioning, HAQ DI, was significantly greater in the combination group, but was not significantly different between etanercept monotherapy and MTX monotherapy (improvements of 1.0, 0.7, and 0.65 respectively). Quality of life was assessed using the European Quality of Life Health Status Visual Analog Scale, and superior improvements in quality of life were reported by patients on combination treatment. ${ }^{39}$

Etanercept treatment was also assessed in MTX-naïve patients with early RA: the COMET study and a study by Bathon et al. ${ }^{22,23}$ COMET assessed etanercept in combination with MTX, and Bathon et al assessed etanercept monotherapy. COMET was different to previous trials in early arthritis, as remission was used for the first time as the study endpoint (DAS28 < 2.6), as opposed to using ACR response criteria. At one year, the proportion of patients who achieved DAS28 remission was greater with etanercept and MTX than with MTX alone ( $50 \%$ compared to $28 \% ; P<0.0001)$. This benefit was sustained at 2 years; $57 \%$ of patients who continued on combination therapy achieved DAS28 remission, compared to $35 \%$ of patients remaining on MTX $(P=0.002){ }^{40}$ This remission rate is greater than that seen in studies of MTXnaïve patients with longer disease duration, such as the TEMPO trial, in which the DAS28 remission rate was $42 \%$ at 2 years with combination treatment. Bathon et al showed etanercept monotherapy was more effective than MTX in the first 6 months, with greater percentages of patients achieving ACR20, ACR50 and ACR70 $(P<0.05)$. At 2 years, there was a significant difference in the proportion of patients achieving ACR 20 ( $72 \%$ vs $59 \%$ of MTX controls; $P=0.005)$, but no significant difference at ACR50 and ACR70 levels. ${ }^{41}$ Patients completing the study by Bathon et al entered an open-label extension study of etanercept monotherapy, extending treatment to 5 years. ${ }^{42}$ Efficacy was maintained for patients who remained on etanercept from the original treatment group, with $68 \%$ fulfilling ACR20 criteria at 5 years.

Both studies also assessed radiographic progression. In the COMET study, no progression (defined as a change in modified total Sharp score of 0.5 or less) was seen in $80 \%$ of patients on etanercept and MTX, compared to $59 \%$ on MTX alone $(P<0.0001)$. Similarly, nonprogression at 2 years was demonstrated more frequently with etanercept monotherapy than with MTX by Bathon et al (63\% compared to $51 \%$; $P=0.017)$. In terms of patient outcomes, COMET showed a significant difference in improvement in HAQ DI score over 1 year between patients receiving etanercept with MTX and MTX alone (improvements of 1.0 and 0.7 respectively; $P<0.001)$. Patients receiving etanercept and MTX also experienced benefits in terms of work stability; of patients in full or part-time work at baseline, $9 \%$ had stopped work at least once during the study, compared to $24 \%$ on MTX 
alone. Bathon et al also showed a difference in improvement in HAQ DI after 2 years; 55\% of etanercept patients had improved by at least 0.5 units, compared to $37 \%$ of MTX patients $(P<0.001)$.

\section{Certolizumab pegol}

Results showing efficacy in rheumatoid arthritis have been reported in patients with RA resistant to 6 months of MTX (RAPID 1 and 2), ${ }^{24,25}$ and patients with RA resistant to 6 months of MTX or other DMARDs (FAST4WARD). ${ }^{26}$ Approximately $80 \%$ of patients in the FAST4WARD study had previously been treated with MTX and, on average, had failed two DMARDs. RAPID 1 and 2 showed efficacy of two different preparations of certolizumab (lyophized and liquid) in combination with MTX, whereas FAST4WARD used certolizumab as monotherapy. Success in achieving clinical response compared to placebo is shown in Table 6. RAPID 1 and RAPID 2 produced similar response rates with the different preparations. Therefore, only data from RAPID 1 is presented here, for simplicity. Clinical responses were maintained to week 52 in RAPID 1 and 2.

Improvement in physical function was significantly greater with certolizumab used in combination with MTX, and as monotherapy, compared to control groups. Mean improvement in HAQ DI was 0.6 at 52 weeks with combination therapy in RAPID 1 , and 0.36 at 24 weeks with monotherapy in FAST4WARD $(P<0.001$ against placebo in both studies). With combination therapy in RAPID 1, inhibition of radiographic progression was significantly greater than MTX alone $(P<0.001)$, but was not assessed in FAST4WARD.

\section{Golimumab}

Efficacy in combination with MTX and as monotherapy has been assessed in patients who are MTX-naïve (GO-BEFORE), ${ }^{28}$ and patients with active RA despite MTX treatment (GO-FORWARD). ${ }^{27}$ Results in terms of ACR response are shown in Table 7.

Golimumab is unique amongst the anti-TNF therapies in that there is randomized controlled trial evidence for its efficacy in patients who have previously received anti-TNF therapy. In the GO-AFTER study, $58 \%$ of patients had received previous anti-TNF treatment that was stopped due to lack of efficacy, and $34 \%$ of patients had received more than one anti-TNF in the past. ${ }^{29}$ Golimumab was given with or without at least one DMARD. Approximately two thirds of patients were taking concomitant MTX. A statistically significant difference was seen compared to placebo in the percentage of patients achieving ACR20 (34\% vs 17\%) and ACR50 responses $(18 \%$ vs 5\%) $(P<0.001$ for both levels of response). There was also a difference in improvement in HAQ DI; mean improvement was 0.3 with golimumab, but 0.0 in controls $(P<0.001)$.

\section{Inhibition of T cell activation: abatacept}

For $\mathrm{T}$ cell activation, in addition to binding to antigen, a costimulatory signal is also necessary. This is produced by the binding of CD28 molecules on the T cell surface to CD80/ CD86 molecules on the surface of an antigen-presenting cell. $\mathrm{T}$ cells are capable of expressing cytotoxic T-lymphocyte antigen 4 (CTLA 4), which binds to CD80/CD86 more readily than $\mathrm{CD} 28$, thereby preventing this second process required for $\mathrm{T}$ cell activation. Abatacept is a recombinant protein consisting of the extracellular domain of CTLA 4 and human immunoglobulin; therefore, it inhibits $\mathrm{T}$ cell activation. ${ }^{43}$ It is given intravenously at a dose of $10 \mathrm{mg} / \mathrm{kg}$ every 4 weeks.

Abatacept has been assessed in combination with DMARD therapy (usually MTX) in randomized controlled trials of patients with established RA which is active despite MTX (AIM and Kremer et al), ${ }^{44,45}$ and despite previous anti-TNF treatment (ATTAIN) ${ }^{46}$. All demonstrated higher

Table 6 The proportion of RA patients achieving the levels of clinical improvement defined by the ACR (American College of Rheumatology) response criteria with combination certolizumab and methotrexate (RAPID I) ${ }^{24}$ and certolizumab monotherapy $\left(\right.$ FAST4WARD) ${ }^{26}$

\begin{tabular}{|c|c|c|c|c|}
\hline & \multicolumn{2}{|l|}{ RAPID I 24} & \multicolumn{2}{|c|}{ FAST4WARD $^{26}$} \\
\hline & MTX + placebo $n=199$ & $\begin{array}{l}\text { MTX + certolizumab } \\
200 \text { mg } 2 \text { weekly } n=393\end{array}$ & $\begin{array}{l}\text { Placebo } \\
n=109\end{array}$ & $\begin{array}{l}\text { Certolizumab } 400 \mathrm{mg} \\
4 \text { weekly } \mathrm{n}=\mathrm{I} \text { I I }\end{array}$ \\
\hline \multicolumn{5}{|c|}{ At 24 wks (\%): } \\
\hline ACR 20 & 14 & $59^{a}$ & 9 & $46^{a}$ \\
\hline ACR 50 & 8 & $37^{a}$ & 4 & $23^{a}$ \\
\hline ACR 70 & 3 & $21^{a}$ & 0 & 6 \\
\hline
\end{tabular}

Note: ${ }^{a}<<0.001$ compared to placebo.

Abbreviations: ACR20, ACR50, ACR70, American College of Rheumatology response criteria improvements of $20 \%, 50 \%$, and $70 \%$; $M$ TX, methotrexate. 
Table 7 The proportion of RA patients achieving the levels of clinical improvement defined by the ACR (American College of Rheumatology) response criteria with combination golimumab and methotrexate and golimumab monotherapy compared to methotrexate monotherapy

\begin{tabular}{|c|c|c|c|c|c|c|}
\hline & \multicolumn{3}{|c|}{ GO-BEFORE ${ }^{28}$} & \multicolumn{3}{|c|}{ GO-FORWARD ${ }^{27}$} \\
\hline & $\begin{array}{l}\text { MTX + } \\
\text { placebo } \\
n=160\end{array}$ & $\begin{array}{l}\text { Golimumab } \\
100 \text { mg } \\
4 \text { weekly } \\
n=159\end{array}$ & $\begin{array}{l}\text { MTX + } \\
\text { golimumab } \\
50 \text { mg } 4 \text { weekly } \\
n=159\end{array}$ & $\begin{array}{l}\text { MTX + } \\
\text { placebo } \\
n=133\end{array}$ & $\begin{array}{l}\text { Golimumab } \\
100 \text { mg } \\
4 \text { weekly } \\
n=133\end{array}$ & $\begin{array}{l}\text { MTX + } \\
\text { golimumab } \\
50 \text { mg } 4 \text { weekly } \\
n=89\end{array}$ \\
\hline \multicolumn{7}{|c|}{ At 24 wks (\%): } \\
\hline ACR 20 & 49 & 52 & $62^{\mathrm{b}}$ & 28 & 35 & $60^{\mathrm{a}}$ \\
\hline ACR 50 & 29 & 33 & $40^{\mathrm{b}}$ & 14 & 20 & $37^{\mathrm{a}}$ \\
\hline ACR 70 & & & & 5 & $11^{b}$ & $20^{\mathrm{a}}$ \\
\hline
\end{tabular}

Notes: a $P<0.001$ compared to placebo group; ${ }^{\mathrm{b}} \mathrm{P}<0.05$ compared to placebo group.

Abbreviations: ACR20, ACR50, ACR70, American College of Rheumatology response criteria improvements of $20 \%, 50 \%$, and $70 \%$; MTX, methotrexate.

rates of clinical improvement and improvement in physical function with abatacept plus DMARD in comparison to DMARD alone (Table 8). In all three studies, significantly more patients in abatacept groups achieved clinically meaningful improvement in HAQ scores $(P<0.001)$. Abatacept has also been shown to improve health-related quality of life. For example, in the ATTAIN study, improvement in PCS and MCS scores of the SF-36 was greater than improvement in the control group at levels of significance of $P<0.001$ and $P<0.01$ respectively. The AIM study also assessed radiographic change, showing approximately $50 \%$ reduction in the progression of radiographic damage when abatacept was added to DMARD treatment; median change in total Genenant-modified Sharp score from baseline was 0.25 with abatacept plus DMARD therapy, compared to 0.53 with DMARD therapy alone $(P=0.012){ }^{44}$
Patients completing these trials were eligible to receive $10 \mathrm{mg} / \mathrm{kg}$ abatacept with DMARD in open-label extension studies. In all three studies, the ACR response rates achieved in the original abatacept groups were maintained at the end of the study periods, in the patients who remained on abatacept. The rate of discontinuation due to lack of efficacy was $2 \%$ over the 1 -year extension period of the AIM trial, ${ }^{47} 11 \%$ over the 4-year extension by Kremer et al ${ }^{48}$ and $16 \%$ over 18 months after the ATTAIN trial (patients who had previously received anti-TNF) ${ }^{49}$ Radiographic progression in the original abatacept group of the AIM trial was significantly slower in the second year of treatment compared to the first, suggesting an increasing effect of abatacept on structural damage in year $2 .^{43}$

Abatacept in combination with MTX was assessed in MTX-naïve patients with early RA (disease duration up to 2 years) and poor prognostic factors (seropositve for rheumatoid factor and/or anti-CCP), and presence of

Table 8 The proportion of RA patients achieving the levels of clinical improvement defined by the ACR (American College of Rheumatology) response criteria with combination abatacept and methotrexate or alternative DMARD compared to DMARD alone

\begin{tabular}{ll} 
AIM $^{44}$ & \\
\hline MTX + & MTX + abatacept \\
placebo & $10 \mathrm{mg} / \mathrm{kg}$ \\
$\mathrm{n}=219$ & 4 weekly \\
& $n=433$
\end{tabular}

\begin{tabular}{ll}
\multicolumn{2}{l}{ Kremer et al ${ }^{45}$} \\
\hline MTX + & MTX + abatacept \\
placebo & $10 \mathrm{mg} / \mathrm{kg}$ \\
$\mathrm{n}=1 \mathrm{I9}$ & 4 weekly \\
& $\mathrm{n}=\mathrm{I}$ I5
\end{tabular}

\begin{tabular}{ll} 
ATTAIN $^{46}$ & \\
\hline DMARD + & DMARD + \\
placebo & abatacept \\
$n=133$ & $10 \mathrm{mg} / \mathrm{kg}$ \\
& 4 weekly \\
& $\mathrm{n}=258$
\end{tabular}

At 6 months (\%):
ACR 20
ACR 50
ACR 70
At I 2 months (\%):
ACR 20
ACR 50
ACR 70

\begin{tabular}{|c|c|c|c|c|c|}
\hline & & & & 20 & $50^{a}$ \\
\hline & & & & 4 & $20^{\mathrm{a}}$ \\
\hline & & & & 2 & 10 \\
\hline 40 & $73^{a}$ & 36 & $63^{a}$ & & \\
\hline 18 & $48^{\mathrm{a}}$ & 20 & $42^{\mathrm{a}}$ & & \\
\hline 6 & $29^{a}$ & 8 & 21 & & \\
\hline
\end{tabular}

Note: ${ }^{a} P<0.001$ compared to placebo group.

Abbreviations: ACR20, ACR50, ACR70, American College of Rheumatology response criteria improvements of $20 \%$, $50 \%$, and $70 \%$; DMARD, disease-modifying antirheumatic drug; MTX, methotrexate. 
radiographic erosions. ${ }^{50}$ Primary endpoints were remission (DAS28 < 2.6) and Genant-modified total Sharp score at 1 year. DAS 28 remission was achieved in $42 \%$ of patients in the abatacept and MTX group, compared to $23 \%$ receiving MTX alone $(P<0.001)$. There was also a significant slowing of radiographic progression (mean change in total score 0.63 vs $1.06 ; P=0.040)$. Results are comparable to anti-TNF in early RA; for example, the COMET study of etanercept. This is particularly impressive, considering that patients were selected based on the basis of poor prognostic factors $(90 \%$ of patients were anti-CCP positive).

Unlike other biologic treatments, the efficacy of abatacept in undifferentiated arthritis has been assessed. ${ }^{51}$ Patients were anti-CCP positive with at least two swollen and tender joints, and therefore highly likely to develop RA, but did not yet fulfil the criteria for the 1987 definition of RA by the American College of Rheumatology. ${ }^{52}$ They were randomized to abatacept or placebo treatment for 6 months. At one year (6 months after treatment was discontinued), $46 \%$ of abatacept-treated versus $67 \%$ of placebo-treated patients developed RA (95\% confidence interval for the difference between the groups: $-47 \%$ to $7 \%$ ). Abatacept also prevented radiographic progression; mean change in Genant-modified Sharp score, from baseline to one year, was 0.01 in abatacepttreated patients vs 1.11 in placebo controls (95\% confidence interval for difference between the groups: -2.05 to -0.15 ).

\section{B cell inhibition: rituximab}

Rituximab is a human-mouse chimeric monoclonal antibody that selectively depletes CD20-expressing B cells. The mechanism by which rituximab depletes $B$ cells may be by cell-mediated or complement-dependant toxicity, or by promotion of apoptosis. ${ }^{53}$ It has been used to treat nonHodgkins lymphoma since 1997, but has since been licensed for use in RA in combination with MTX ${ }^{54}$ It is administered in two intravenous infusions of $1 \mathrm{~g}$, two weeks apart, with intravenous glucocorticoid. Usually, a clinical response is seen at 16 weeks and lasts at least 6 months, after which treatment can be repeated. Usually, response to re-treatment is similar to the initial response. ${ }^{55}$ Response has been shown to be related to the level of B cell depletion in the blood after the first infusion; at 12 months, 59\% of patients with complete depletion of B cells (below $0.0001 \times 10^{9} /$ liter) still had a moderate to good clinical response, compared to $21 \%$ of patients with partial depletion. ${ }^{56}$ Vital et al demonstrated that patients who were not clinically responding to rituximab at 6 months had higher B cell concentrations prior to treatment than responders, and were less likely to achieve complete depletion after the first infusion. ${ }^{57}$ When these nonresponders were re-treated with rituximab after 6 months $72 \%$ achieved a clinical response.

An initial open-label phase IIa study by Edwards et al assessed clinical response when rituximab was used alone and in combination with MTX or cyclophosphamide, compared to MTX alone. ${ }^{58}$ Cyclophophamide (750 mg on days 3 and 17) was used due to prior success of rituximab in treatment of lymphoma in the CHOP regimen (cyclophosphamide, hydroxydoxorubicin, vincristine and prednisolone). At 24 and 48 weeks, greater numbers of patients achieved ACR20 responses in all rituximab groups compared to MTX alone, but the difference was only significant for rituximab in combination with MTX (Table 9). The percentage of patients achieving a meaningful improvement in HAQ DI (decrease of $\geq 0.22$ from baseline) was greatest in the rituximab-MTX

Table 9 The proportion of RA patients achieving the levels of clinical improvement defined by the ACR (American College of Rheumatology) response criteria with rituximab at the dose commonly used in clinical practice (I000 mg on day I and day I5)

\begin{tabular}{|c|c|c|c|c|c|c|c|c|}
\hline & \multicolumn{4}{|c|}{ Edwards et $\mathrm{al}^{58}$} & \multicolumn{2}{|c|}{ DANCER $^{53}$} & \multicolumn{2}{|c|}{ REFLEX ${ }^{60}$} \\
\hline & $\begin{array}{l}\text { MTX } \\
n=40\end{array}$ & $\begin{array}{l}\text { Rituximab } \\
n=40\end{array}$ & $\begin{array}{l}\text { CYC + } \\
\text { rituximab } \\
n=4 I\end{array}$ & $\begin{array}{l}\mathrm{MTX}+ \\
\text { rituximab } \\
\mathrm{n}=40\end{array}$ & $\begin{array}{l}\text { MTX + } \\
\text { placebo } \\
n=|2|\end{array}$ & $\begin{array}{l}\text { MTX + } \\
\text { rituximab } \\
n=1 / 5\end{array}$ & $\begin{array}{l}\text { MTX + } \\
\text { placebo } \\
n=209\end{array}$ & $\begin{array}{l}\text { MTX + } \\
\text { rituximab } \\
\mathbf{n}=3 \text { I I }\end{array}$ \\
\hline \multicolumn{9}{|c|}{ At 24 wks (\%): } \\
\hline ACR 20 & 38 & 65 & 76 & 73 & 28 & $54^{\mathrm{a}}$ & 18 & $51^{a}$ \\
\hline ACR 50 & 13 & 33 & 41 & 43 & 13 & $34^{\mathrm{a}}$ & 5 & $27^{\mathrm{a}}$ \\
\hline ACR 70 & 5 & 15 & 15 & 23 & 5 & $20^{\mathrm{a}}$ & I & $12^{\mathrm{a}}$ \\
\hline \multicolumn{9}{|c|}{ At 48 wks (\%): } \\
\hline ACR 20 & 20 & 33 & 49 & $65^{a}$ & & & & \\
\hline ACR 50 & 5 & 15 & 27 & 35 & & & & \\
\hline ACR 70 & 0 & 10 & 10 & 15 & & & & \\
\hline
\end{tabular}

Note: ${ }^{a} P<0.001$ compared to placebo group.

Abbreviations: ACR20, ACR50, ACR70, American College of Rheumatology response criteria improvements of $20 \%, 50 \%$, and $70 \%$; CYC, cyclophosphamide; MTX, methotrexate. 
group (68\% vs $39 \%$ and $43 \%$ in other rituximab groups and $28 \%$ in the MTX monotherapy group). Follow-up was continued two years after rituximab treatment. In this time, a number of patients discontinued from the study due to lack of efficacy or relapse, and received alternative therapy or retreatment with rituximab. At two years, $45 \%$ of patients in the rituximab-MTX group had not required further treatment, compared to $22 \%$ in the rituximab plus cylophosphamide group, $10 \%$ in the rituximab monotherapy group, and 15\% in the MTX-only group.

The DANCER trial investigated differing doses of rituximab with MTX, with or without glucocorticoids, in patients with active RA despite at least three months of MTX treatment. ${ }^{53}$ Beyond 4 weeks, clinical response was not significantly affected by glucocorticoid treatment, but ameliorated acute infusion reactions. Therefore, results were pooled according to rituximab dose. When results for rheumatoid factor-negative patients were analyzed (85 out of 465 patients), rituximab showed no superior efficacy over placebo (48\% achieved ACR20 at 24 weeks compared to $52 \%$ of controls), and their results were excluded from the main analysis (Table 9). The proportion of patients who had a meaningful decrease in HAQ DI ( $\geq 0.22$ from baseline) was $67 \%$ with rituximab, compared to $34 \%$ in controls. $^{59}$

Patients enrolled in the REFLEX trial had active RA despite three months of MTX treatment, and had failed previous anti-TNF treatment, either due to lack of efficacy (90\% of patients) or intolerance. ${ }^{60}$ Rituximab had a significant affect on HAQ DI (mean improvement of 0.4 compared to 0.1 in controls; $P<0.0001$ ), and on quality of life (mean improvement in PCS was 5.8 vs 0.9 , and MCS was 4.7 vs $1.3 ; P=0.0002$ for both scores). The effect of rituximab on radiographic progression was assessed by comparing Genantmodified Sharp scores at week 24 to baseline. A trend was seen towards reduction of radiographic progression. However, results did not reach statistical significance; mean change in total score in the rituximab group was 0.6 compared to 1.2 in controls $(P=0.169)$.

\section{II-6 inhibition: tocilizumab}

Amongst its many roles, Il-6 is involved in differentiation of $\mathrm{B}$ cells into plasma cells, and activation of T cells. ${ }^{61,62}$ Tocilizumab is an antibody against the Il-6 receptor, inhibiting Il-6 binding, and is produced from human immunoglobulin and mouse antibody to the human Il-6 receptor by recombinant DNA technology. It is administered intravenously every 4 weeks.

Tocilizumab was used alone and in combination with MTX in the CHARISMA trial, in patients with an inadequate response to MTX. ${ }^{63}$ The study showed the greatest number of patients who achieved the primary endpoint (ACR20 at 20 weeks) were those treated with tocilizumab $8 \mathrm{mg} / \mathrm{kg}$ plus MTX (74\% compared to $41 \%$ in the placebo plus MTX group; $P=0.001)$. This is the dose used in clinical practice. Response with tocilizumab $8 \mathrm{mg} / \mathrm{kg}$ monotherapy was less impressive (Table 10).

Further evidence of efficacy of tocilizumab in combination with MTX or other DMARDs is available (Table 10). The OPTION study included patients with an inadequate response to MTX. A small number had received previous anti-TNF treatment (51 patients; 8\%). ${ }^{64}$ The TOWARD study assessed the combination of tocilizumab with other conventional DMARDs in patients with active RA despite eight weeks of treatment with DMARD therapy. ${ }^{65}$ Approximately $75 \%$ of patients were receiving MTX as the concomitant DMARD. Improved quality of life was seen in tocilizumab groups in both studies, with statistically significant differences between mean improvements from baseline in MCS and PCS scores $(P \leq 0.001)$.

Table 10 The proportion of RA patients achieving the levels of clinical improvement defined by the ACR (American College of Rheumatology) response criteria with tocilizumab monotherapy and in combination with methotrexate or DMARD. Tocilizumab groups received $8 \mathrm{mg} / \mathrm{kg}$ every 4 weeks

\begin{tabular}{|c|c|c|c|c|c|c|c|c|c|}
\hline & \multicolumn{3}{|c|}{ CHARISMA $^{63}$} & \multicolumn{2}{|c|}{ OPTION ${ }^{64}$} & \multicolumn{2}{|c|}{ TOWARD ${ }^{65}$} & \multicolumn{2}{|c|}{ RADIATE ${ }^{66}$} \\
\hline & $\begin{array}{l}\text { MTX + } \\
\text { placebo } \\
n=49\end{array}$ & $\begin{array}{l}\text { TCZ } \\
n=52\end{array}$ & $\begin{array}{l}\text { MTX + } \\
\text { TCZ } \\
n=50\end{array}$ & $\begin{array}{l}\text { MTX + } \\
\text { placebo } \\
\mathbf{n}=204\end{array}$ & $\begin{array}{l}\text { MTX + } \\
\text { TCZ } \\
n=205\end{array}$ & $\begin{array}{l}\text { DMARD + } \\
\text { placebo } \\
n=415\end{array}$ & $\begin{array}{l}\text { DMARD + } \\
\text { TCZ } \\
\mathbf{n}=\mathbf{8 0 5}\end{array}$ & $\begin{array}{l}\text { MTX + } \\
\text { placebo } \\
n=160\end{array}$ & $\begin{array}{l}\text { MTX + } \\
\text { TCZ } \\
n=175\end{array}$ \\
\hline \multicolumn{10}{|c|}{ 20-24 wks (\%): } \\
\hline ACR 20 & 41 & 63 & $74^{\mathrm{a}}$ & 26 & $59^{a}$ & 25 & $61^{a}$ & 10 & $50^{a}$ \\
\hline ACR 50 & 29 & 41 & 53 & 11 & $44^{a}$ & 9 & $38^{\mathrm{a}}$ & 4 & $29^{a}$ \\
\hline ACR 70 & 16 & 16 & 37 & 2 & $22^{\mathrm{a}}$ & 3 & $21^{a}$ & I & $12^{\mathrm{a}}$ \\
\hline
\end{tabular}

Note: ${ }^{a}<0.001$ compared to placebo.

Abbreviations: ACR20, ACR50, ACR70, American College of Rheumatology response criteria improvements of $20 \%$, $50 \%$, and $70 \%$; DMARD, disease-modifying antirheumatic drugs; MTX, methotrexate; TCZ, tocilizumab. 
RADIATE was a trial in RA patients who had received one or more anti-TNF therapies in the previous year but had failed treatment due to lack of efficacy or intolerance (approximately half of patients had failed more than one anti-TNF). ${ }^{66}$ The results are similar to those seen with rituximab subsequent to failed anti-TNF in the REFLEX study, with half of patients achieving an ACR20 response, compared to $10 \%$ of patients on MTX alone.

Affect on radiographic progression was assessed in the SAMURAI and LITHE studies. ${ }^{67,68}$ In the SAMURAI study, patients with an inadequate response to DMARD therapy were randomized to tocilizumab monotherapy or continuing conventional DMARD treatment. At one year, the tocilizumab group showed less radiographic progression, with a mean change in total Sharp score of 2.3 compared to 6.1 in the DMARD group $(P<0.01)$. The LITHE study was a double-blind randomized controlled trial of tocilizumab combined with MTX, compared to MTX monotherapy, in MTX nonresponders. Again, the tocilizumab group showed less progression, with mean change in total Genant-modified Sharp score of 1.3 compared to $3.0(P<0.0001)$.

In MTX-naïve patients, the AMBITION study compared efficacy of tocilizumab monotherapy to MTX ${ }^{69}$ A significantly higher proportion of patients receiving tocilizumab achieved ACR20 response at 24 weeks (70\% compared to $53 \% ; P<0.0001)$, and one third of patients achieved DAS28 remission, compared to $12 \%$ of patients receiving MTX.

For the purpose of analyzing long-term efficacy, patients from these randomized controlled trials (OPTION, TOWARD, RADIATE, LITHE, and AMBITION) were enrolled in long-term extension studies, in which all patients receive tocilizumab for up to five years, and are currently ongoing. Interim results at 2.5 years have been published, showing continued improvement of ACR responses over time, and only $3 \%$ withdrawal rate due to lack of efficacy. ${ }^{70}$

\section{Tolerability}

In trials, rates of adverse events with anti-TNF treatments, and discontinuation rates due to adverse events, are generally comparable to rates seen in control groups. For example, the ATTRACT study demonstrated that adverse events were as common in all infliximab groups as in the placebo group. ${ }^{11}$ An adverse event was reported at least once in $80 \%$ of patients. However, these were well-tolerated, causing the discontinuation of treatment in 3\%-7\% of patients across infliximab treatment groups, which compared to $8 \%$ in the placebo group. Infusion reactions were more common with infliximab (16\%-20\% compared to $10 \%$ in the placebo group), but were usually mild and transient. In the STAR study (Safety Trial of Adalimumab in Rheumatoid Arthritis), patients were randomized to adalimumab or placebo, and continued on their conventional DMARDs. ${ }^{71}$ There was no significant difference in total adverse event rates $(87 \%$ with adalimiumab vs $83 \%$ with placebo), and when the type of event was considered, a significant difference between groups was only seen in injection site reactions ( $20 \%$ vs $12 \%)$, rash ( $11 \%$ vs $6 \%$ ), and back pain ( $5 \%$ vs $3 \%$ ). The TEMPO trial of etanercept as monotherapy and in combination with MTX reported similar total adverse event rates $(81 \%$ and $86 \%$ respectively, compared to $81 \%$ with MTX monotherapy). ${ }^{21}$ In terms of type of event, a significant increased incidence with etanercept was only seen in injection site reactions.

Certolizumab and golimumab have been shown to differ from other anti-TNF therapies in that rate of injection site reactions are not increased compared to controls. In the FAST4WARD study, the rate of injection site reactions was $5 \%$ with certolizumab compared to $14 \%$ with placebo. ${ }^{26}$ In GO-FORWARD the rate was $2 \%$ with golimumab compared to $3 \%$ in controls. ${ }^{27}$

Trials have shown tolerability of abatacept is similar to anti-TNF treatment in RA. For example, the total adverse event rates in the AIM study were $87 \%$ with abatacept compared to $84 \%$ with placebo. ${ }^{44}$ The longest running open-label extension trial of abatacept treatment, by Kremer et al reported a $17 \%$ discontinuation rate due to adverse events over 5 years. ${ }^{48}$

With rituximab, the most frequent adverse events are infusion reactions. These are reduced by premedication with intravenous glucocorticoid, but remain common with the first infusion of each course; acute infusion reaction occurred in $29 \%$ of patients treated with two doses of $1000 \mathrm{mg}$ rituximab in the DANCER study, and $23 \%$ of patients in the REFLEX study. ${ }^{53,60}$ The rate decreases for the second infusion (approximately 10\%). Total adverse events occurred in $85 \%$ of patients receiving two doses of $1000 \mathrm{mg}$ rituximab in both DANCER and REFEX trials (compared to rates of $70 \%$ and $88 \%$ in placebo groups). They were largely welltolerated; adverse events led to withdrawal of treatment in $3 \%$ of patients in both trials.

In the largest randomized controlled trial of tocilizumab (the TOWARD study of 1,220 patients), the incidence of adverse events was higher in the tocilizumab group compared to controls ( $73 \%$ compared to $61 \%$ ). The majority of events though were mild to moderate in severity and generally tolerated; the discontinuation rate due to adverse events was $4 \%$, compared to $2 \%$ for controls. ${ }^{65}$ 


\section{Safety of biologics}

There are important safety issues with the use of biologic therapy, not least because their targets in the immune system have a role in the body's defence against infection and malignancy. Difficulties arise in assessing their safety, as any increase in rates of malignancy and infection (both of which are associated with RA) may reflect greater disease severity and not biologic treatment. Evidence of their safety is available from registries of patients receiving biologics; for example, the British Society for Rheumatology Biologics Register (BSRBR). This includes a control group of 3,106 RA patients treated with DMARDs, but these patients are likely to have less severe disease if they have not required biologic therapy. Randomized controlled trials are generally not powered to detect rare adverse effects such as malignancy. Meta-analyses of trials may go a way towards solving this issue. However, it is important to note that trials may exclude patients with co-morbidities, and therefore their results may not apply to the general RA population.

\section{Infection}

There is an increased risk of infection with biologic therapy, and they are contraindicated in the presence of active, severe infection. Risk of serious infection (infection requiring intravenous antibiotics, or leading to hospitalization or death) with biologic treatment is summarized in Table 11.

There is an increased risk of tuberculosis (TB), either reactivation of latent infection or increased susceptibility to infection. It can present atypically, for example, as extra-pulmonary or miliary TB. Out of the 10,403 patients on anti-TNF therapy in the BSRBR, there have been 35 cases of TB, with no cases in the DMARD group. ${ }^{76}$ There is a difference in risk within the group of anti-TNFs. Adalimumab and infliximab (the monoclonal antibodies) are associated with higher rates compared to the receptor fusion protein etanercept. This may be due to differences in their mechanism of action. The monoclonal antibodies also inhibit $\mathrm{T}$ cell activation and the production of interferon gamma, whereas the function of interferon gamma is preserved with etanercept treatment. ${ }^{77}$ All patients should be screened for latent infection prior to receiving anti-TNF. The optimal treatment for latent TB prior to commencing anti-TNF treatment has not been investigated in trials. Observational data, for example, from the Spanish biologics registry, reports that screening for TB and treatment with isoniazid prior to anti-TNF therapy significantly decreases
Table I I Risk of serious infection with biologic treatment

\begin{tabular}{|c|c|}
\hline $\begin{array}{l}\text { Biologic } \\
\text { agent }\end{array}$ & Risk of serious infection \\
\hline Anti-TNF & $\begin{array}{l}\text { A meta-analysis of trials of infliximab and } \\
\text { adalimumab calculated the risk was approximately } \\
\text { double that with conventional DMARD } \\
\text { treatment (odds ratio } 2.0 \text {; } 95 \% \text { confidence } \\
\text { interval: I.3 to } 3 . I \text { ). }{ }^{72} \\
\text { A retrospective observational study of over } 700 \\
\text { patients on anti-TNF compared the incidence of } \\
\text { serious infections on treatment to the incidence } \\
\text { in the same patients prior to treatment. }{ }^{73} \text { Rates } \\
\text { of serious infection in the first year were } 10 \text { per } \\
\text { I00 patient years compared to } 3 \text { per } 100 \text { patient } \\
\text { years prior to anti-TNF treatment. } \\
\text { The rate of serious infection from BSRBR data } \\
\text { was } 6 \text { per I00 patient years. }{ }^{74} \text { When adjustment } \\
\text { was made for confounding factors such as } \\
\text { co-morbidities, this was not significantly different } \\
\text { from the rate in patients on conventional } \\
\text { DMARDs. However, when the incidence rate } \\
\text { over the first } 90 \text { days of anti-TNF treatment was } \\
\text { calculated, a four-fold increase in serious } \\
\text { infections was seen in this initial period of } \\
\text { treatment. }\end{array}$ \\
\hline Abatacept & $\begin{array}{l}\text { In the open-label extension trials discussed } \\
\text { previously, the rate of serious infections was } 3-5 \\
\text { per } 100 \text { patient years across the studies. }{ }^{47-49}\end{array}$ \\
\hline Rituximab & $\begin{array}{l}\text { In the DANCER and REFLEX trials, incidence of } \\
\text { serious infection was } 5 \text { per } 100 \text { patient years in } \\
\text { both trials (compared to rates of } 3-4 \text { per } 100 \\
\text { patient years in control groups). }{ }^{53,60} \text { Long-term } \\
\text { safety data with repeated treatments has shown } \\
\text { similar rates of serious infection for each cycle of } \\
\text { treatment. }^{75}\end{array}$ \\
\hline Tocilizumab & $\begin{array}{l}\text { In the TOWARD study, the rate of serious } \\
\text { infection was } 6 \text { per } 100 \text { patient years, compared } \\
\text { to } 5 \text { per } 100 \text { patient years with DMARD therapy } \\
\text { alone. }^{65}\end{array}$ \\
\hline
\end{tabular}

Abbreviation: BSRBR, British Society for Rheumatology Biologics Register.

the risk, but does not eliminate it. ${ }^{78}$ There is no evidence that rituximab increases the risk of TB in clinical trials. Trials excluded patients with active TB or latent TB on chest X-ray, but have not screened for latent TB by purified protein derivative testing.

Anti-TNF treatments are contraindicated in chronic hepatitis B infection, as infliximab has been associated with viral reactivation in a number of case reports. ${ }^{76}$ Etanercept is considered to be safe in hepatitis C. A prospective study of eight patients and a randomized controlled trial have shown no increase in viral load or adverse events with etanercept. ${ }^{80,81}$ Hepatitis B reactivation has been reported after rituximab treatment in lymphoma patients, but successful treatment with prophylaxis has been possible. RA trials have screened 
for hepatitis B and $\mathrm{C}$ prior to treatment. Therefore, screening for hepatitis $\mathrm{B}$ and $\mathrm{C}$ is recommended. ${ }^{54}$

There are case reports of fungal infections with antiTNF therapy, for example, histoplasmosis or aspergillosis, although the incidence is extremely low. ${ }^{79}$

\section{Malignancy}

There is concern that anti-TNF and abatacept therapies may put patients at risk of malignancy due to the role of TNF and $\mathrm{T}$ cells in cancer immunosurveillance.

A meta-analysis of adalimumab and infliximab trials has shown increased rates of malignancy compared to placebo or placebo plus DMARD (pooled odds ratio 3.3; 95\% confidence interval: 1.2 to 9.1 ). However, these trials included high doses of infliximab $(6 \mathrm{mg} / \mathrm{kg}$ every eight weeks or more). ${ }^{72}$ Observational studies indicate that anti-TNF therapy is associated with an increased risk of nonmelanotic skin cancers but not solid tumor malignancies. For example, a study of approximately 3,000 patients treated with anti-TNF in the United States of America reported an incidence rate of nonmelanotic skin cancer of 26 per 1,000 patient years, compared to 20 per 1,000 patient years in patients treated with conventional DMARDs. ${ }^{82}$ A Swedish study reported a standardized incidence rate of solid tumors of 0.9 in 4,000 RA patients on anti-TNF, which compared to the standard incidence rate of 1.05 in over 50,000 RA patients. ${ }^{83}$ However, anti-TNF may have been avoided in patients at risk of malignancy, or with a previous history of malignancy, because of a theoretical risk. Data available from the BSRBR, of patients with a history of previous malignancy, does not demonstrate any increased cancer risk with anti-TNF. ${ }^{84}$

Anti-TNF treatment is contraindicated in patients with a history of a lymphoproliferative disorder within the last five years. There have been reports of higher incidence rates of lymphoma in patients on anti-TNF therapies in comparison to rates seen in the general RA population; for example, the French RATIO registry data. ${ }^{85}$ In other cohort studies however, such as the Swedish cohort described above, no increase in incidence has been seen. ${ }^{86}$

With abatacept, a total of 42 malignancies were seen in the 1,167 patients who were exposed to at least one dose of abatacept in the open-label extension studies discussed previously. ${ }^{47-49}$ The commonest types were nonmelanotic skin cancers (21 cases), pulmonary malignancy (6 cases), and lymphoma (3 cases). This incidence of pulmonary neoplasm and lymphoma is similar to that in the RA population.

\section{Anaphylaxis}

Infliximab has a higher propensity than other anti-TNF therapies to cause anaphylaxis, as it is a chimeric molecule, but maybe also because it is administered intravenously. In the START study (Safety Trial for Rheumatoid Arthritis with Remicade Therapy), 5 out of 1,442 patients treated with infliximab developed serious infusion reactions. ${ }^{87}$

Rituximab, another chimeric molecule, is contraindicated in patients who have had a hypersensitivity reaction to infliximab. In the REFLEX study, only two infusion reactions out of 308 rituximab-treated patients were reported as severe, one reaction being anaphylaxis, the other hypertension. ${ }^{60}$

\section{Autoimmune syndromes and psoriasis}

Anti-TNF therapy is associated with the production of autoantibodies (antinuclear antibodies and double-stranded DNA antibodies). Rarely, anti-TNF can cause autoimmune hepatitis, vasculitis, and drug-induced systemic lupus erythematosus (occurring in approximately $0.2 \%$ of patients). ${ }^{79}$ These conditions generally improve with drug withdrawal. There are also reports of new-onset of skin psoriasis and worsening of existing psoriasis on anti-TNF therapy. There have been 25 new cases of psoriasis in patients on anti-TNF treatment in the BSRBR, equivalent to an incident rate of 1.04 per 1,000 patient years, compared to no cases in patients on conventional DMARDs. ${ }^{88}$

Autoimmune syndromes have also been seen with abatacept. The extension studies reported vasculitis in 9 patients. ${ }^{47-49}$ Other, rarer events were sicca syndrome (3 patients), erythema nodosum ( 2 patients), multiple sclerosis, systemic lupus erythematosus, and sjögrens syndrome (1 patient each). There were 16 new cases of psoriasis.

\section{Neurological}

Anti-TNF is contraindicated in patients with a history of Parkinson's disease or demyelinating conditions such as optic neuritis or multiple sclerosis, and treatment should be stopped if these disorders occur on treatment. Case reports of development of demyelinating disorders on anti-TNF therapy have been published. ${ }^{79}$ The role of anti-TNF therapy in their causality is impossible to prove, but is suggested by the fact that they generally improve, at least partially, on drug withdrawal.

After treatment with rituximab, the very rare but usually fatal condition of progressive multifocal leukoencephalopathy has been seen. A review of cases from post-marketing surveillance and published literature up until December 2008 
revealed 57 cases ${ }^{89}$ Cases were in patients with known risk factors for the disease, including lymphoma and treatment with additional potent immunosupressants. This included one patient with RA who had previously received chemotherapy for oral malignancy.

\section{Hematological}

Pancytopenia and aplastic anemia while on anti-TNF therapy have been reported. Again, it is difficult to conclude that this is caused by anti-TNF treatment, as these cases are extremely rare, ${ }^{79}$ but if these conditions develop, anti-TNF treatment should be stopped.

Neutropenia is a complication of tocilizumab treatment In the TOWARD study, $29 \%$ of patients in the tocilizumab group had neutrophil levels below the normal range, compared to $4 \%$ of patients in the control group. ${ }^{65}$ Importantly, neutropenia was not associated with any infection-related adverse events. Only $4 \%$ had severe neutropenia (neutrophils less than 500 per $\mathrm{mm}^{3}$ ).

\section{Cardiovascular}

Patients with rheumatoid arthritis have a higher incidence of cardiovascular disease than the general population, with a cardiovascular mortality rate of approximately 1.5 times higher than the general population. ${ }^{2}$ Raised levels of inflammatory markers and cytokines are associated with increased risk of cardiovascular disease, and research has shown levels of TNF are increased in congestive heart failure. On this basis, randomized controlled trials of etanercept in congestive heart failure were conducted, but were terminated early due to higher mortality rates with etanercept treatment. ${ }^{90}$ There are also reports of new-onset congestive heart failure and worsening of existing heart failure with anti-TNF therapy (without other identifiable risks or precipitating factors). Anti-TNF therapy is therefore contraindicated in moderate to severe heart failure (New York Heart Association class III or IV). Rituximab is also contraindicated in severe heart failure (New York Heart Association class IV), but data is not available in patients with heart failure in classes I to III. ${ }^{70}$

Tocilizumab, by suppressing the effect of IL- 6 on the liver, is associated with increased lipid levels (which are suppressed by inflammation). For example, the TOWARD study revealed low-density lipoprotein cholesterol increased to over $160 \mathrm{mg} / \mathrm{dl}$ in $16 \%$ of patients, compared to $3 \%$ of controls. ${ }^{65}$ Levels improve with lipid-lowering therapy. However, the implication for long-term cardiovascular safety is uncertain.

\section{Pregnancy}

There is a lack of evidence for the safety of biologic therapy in pregnancy and lactation. There is data available for 32 pregnancies in the BSRBR. ${ }^{91}$ Twenty three women were receiving anti-TNF therapy at the time of conception, and the majority ( 21 women) discontinued anti-TNF during the first trimester. Of these 23 pregnancies, first trimester miscarriage occurred in 6 , elective miscarriage in 3 , and out of 14 live births there were no congenital malformations. Three of the women who spontaneously miscarried were also taking MTX, which makes this data difficult to interpret.

\section{Discussion}

Rheumatoid disease, being a chronic condition, requires drug treatments that are effective, well-tolerated, and safe over the long term. Although it is generally not immediately life-threatening, it can lead to significant disability, job loss, and systemic complications such as cardiovascular disease. Benefits need to be balanced against potential risks of biologic treatments.

Patients and physicians need to be aware of the risks with biologic treatment, which include an increased risk of infection (all biologics), development of autoimmunity (anti-TNF therapy and abatacept), and deterioration of heart failure (anti-TNF and possibly rituximab). Prior to treatment, patients should be fully assessed for potential risks. Screening for TB and hepatitis is recommended due to the risk of reactivation with anti-TNF. The potential increased risk of lymphoma with anti-TNF treatment remains unclear. A history of a lymphoproliferative disease within the last five years remains a contraindication to anti-TNF. Although adverse event rates with biologic treatment are high in randomized studies, they are generally comparable to rates with conventional DMARDs. The exception to this is infusion or injection site reactions. However, these are mostly well-tolerated and decrease over time, only infrequently leading to drug discontinuation.

Biologic therapies are available for patients with RA who are resistant to conventional DMARDs. Trials have demonstrated the efficacy of biologics over conventional DMARDs in these circumstances, with greater proportions of patients achieving ACR20 responses. For example, one of the earliest trials, the ATTRACT study, showed that patients were twice as likely to achieve an ACR20 response at one year with infliximab and MTX treatment compared to MTX alone. ${ }^{12}$ This holds clinical meaning for patients. An ACR20 is a composite endpoint that includes 
improvement in the number of swollen and tender joints, but also the individual patient's assessment of their pain, health, and physical functioning. Trials have also reported the proportion of patients achieving meaningful improvement in physical functioning and health-related quality of life. This perhaps carries more meaning for patients than do reports of the average improvement in scores, which could be affected by a dramatic improvement in a small minority of patients. It should be noted that the majority of studies discussed in this review are of patients with active arthritis with high tender and swollen joint counts at enrolment. In clinical practice, patients often have lower tender and swollen joint counts. Therefore, the responses seen in the trials discussed here may not be directly applicable to a number of patients.

Several anti-TNF drugs have been developed, with different methods of administration but similar efficacy. A range of available anti-TNF therapies has been important for clinical practice, as some patients develop side-effects specific to certain drugs, and others may not respond or may lose their initial response to therapy. In the latter, there is observational evidence that switching to alternative anti-TNF is successful. ${ }^{92}$ In the case of golimumab, there is evidence from a randomized controlled trial. ${ }^{29}$ Other classes of biologics have proved necessary because, in a proportion of patients, anti-TNF is ineffective or is contraindicated; for example, in patients with malignancy. Evidence for the use of the other classes of biologics in anti-TNF nonresponders is available from clinical trials of abatacept, ${ }^{46}$ rituximab, ${ }^{60}$ and tocilizumab. ${ }^{66}$ Approximately half of patients on these treatments were achieving ACR20 responses at 6 months, which is striking, considering these were patients with disease that had been difficult to treat.

Efficacy of biologic treatments has been assessed in patients recently diagnosed with RA who have not yet failed conventional treatments such as MTX. ${ }^{13,17,23,33,50,69}$ These studies have shown that a greater proportion of patients achieve the higher levels of improvement (ACR50 and ACR70 responses), and higher rates of clinical remission, with biologics compared to conventional DMARDs. For example, the COMET study showed that patients were nearly twice as likely to achieve remission with etanercept and MTX compared to MTX alone after one year (remission rates of $50 \%$ compared to $28 \%$ ). ${ }^{22}$ Improved rates of remission in the early stages of disease may have important consequences for the future in these individuals. For instance, as onset of rheumatoid disease occurs most commonly in middle age, any disruption of a person's ability to work at this stage could have implications for their later career. It may also be important in preventing early joint damage, which is more rapid in the early stages of the disease, and so limit future disability from structural deformities. Both of these aspects of efficacy of early biologic treatment have been demonstrated; for example, reduction in job loss (in the PROWD study) ${ }^{18}$ and prevention of structural damage (in the COMET study). ${ }^{22}$

It has been suggested that early biologic treatment may arrest the disease if used early in its course, and that long-term remission after cessation of biologic treatment may be achievable. For example, drug withdrawal was most successful in the infliximab arm of the BeSt study; ${ }^{14}$ sustained remission one year after withdrawal of infliximab was achieved by Quinn et al in very early RA;33 and reduction in rate of progression of undifferentiated arthritis to RA has been seen six months after withdrawal of abatacept. ${ }^{52}$ As discussed above, biologic therapies are not without any safety concerns and are financially costly. Therefore, it has been proposed that if biologic therapies were available as first-line treatments in clinical practice, patients should be selected, perhaps by predictors of poor prognosis. ${ }^{93}$ Initial financial cost may be offset if biologic therapy enables more young people to stay in work, reducing long-term healthcare costs by preventing later disability and other consequences of RA such as cardiovascular disease, and especially if drug-free remission can be attained.

\section{Disclosure}

The authors report no conflicts of interest in this work.

\section{References}

1. Helmick CG, Felson DT, Lawrence RC, et al; National Arthritis Data Workgroup. Estimates of the prevalence of arthritis and other rheumatic conditions in the United States. Arthritis Rheum. 2008;58:15-25.

2. Södergren A, Stegmayr B, Lundberg V, Öhman ML, Wållberg-Jonsson S. Increased incidence of and impaired prognosis after acute myocardial infarction among patients with seropositive rheumatoid arthritis. Ann Rheum Dis. 2007;66:263-266.

3. Yelin E, Henke C, Epstein W. The work dynamics of the person with rheumatoid arthritis. Arthritis Rheum. 1987;30:507-512.

4. Machold KP, Stamm TA, Enbrel GJM, et al. Very recent onset arthritis - clinical, laboratory, and radiological findings during the first year of disease. J Rheumatol. 2002;29:2278-2287.

5. Grigor C, Capell H, Stirling A, et al. Effect of a treatment strategy of tight control for rheumatoid arthritis (the TICORA study): a single-blind randomised controlled trial. Lancet. 2004;364:263-269.

6. Verstappen SMM, Jacobs JWG, van der Veen MJ, et al. Intensive treatment with methotrexate in early rheumatoid arthritis: aiming for remission. Computer Assisted Management in Early Rheumatoid Arthritis (CAMERA, an open-label strategy trial). Ann Rheum Dis. 2007;66:1443-1449.

7. Choy EHS, Panayi GS. Cytokine pathways and joint inflammation in rheumatoid arthritis. N Engl J Med. 2001;344:909-916. 
8. Felson DT, Anderson JJ, Boers M, et al. ACR preliminary definition of improvement in rheumatoid arthritis. Arthritis Rheum. 1995;38: 727-735.

9. Kosinski M, Zhao SZ, Dedhiya S, Osterhaus JT, Ware JE. Determining minimally important changes in generic and disease-specific healthrelated quality of life questionnaires in clinical trials of rheumatoid arthritis. Arthritis Rheum. 2000;43:1478-1487.

10. Genant HK, Peterfy CG, Westhovens R, et al. Abatacept inhibits progression of structural damage in rheumatoid arthritis: results from the longterm extension of the AIM trial. Ann Rheum Dis. 2008;67: 1084-1089.

11. Maini R, St Clair EW, Breedveld F, et al; the ATTRACT Study Group. Infliximab (chimeric anti-tumour necrosis factor monoclonal antibody) versus placebo in rheumatoid arthritis patients receiving concomitant methotrexate: a randomised phase III trial. Lancet. 1999;354: 1932-1939.

12. Lipsky PE, van der Heijde DMFM, St Clair EW, et al; the ATTRACT Study Group. Infliximab and methotrexate in the treatment of rheumatoid arthritis. $N$ Engl J Med. 2000;30:1594-1602.

13. St Clair EW, van der Heijde DMFM, Smolen JS, et al. Combination of infliximab and methotrexate therapy for early rheumatoid arthritis. A randomized, controlled trial. Arthritis Rheum. 2004;50: 3432-3443.

14. Goerkoop-Ruiterman YPM, de Vries-Bouwstra JK, Allaart CF, et al. Comparison of treatment strategies in early rheumatoid arthritis. A randomised trial. Ann Intern Med. 2007;146:406-415.

15. Weinblatt ME, Keystone EC, Furst DE, et al. Adalimumab, a fully human anti-tumor necrosis factor monoclonal antibody, for the treatment of rheumatoid arthritis in patients taking concomitant methotrexate. The ARMADA trial. Arthritis Rheum. 2003;48:35-45.

16. van der Putte LBA, Atkins C, Malaise M, et al. Efficacy and safety of adalimumab as monotherapy in patients with rheumatoid arthritis for whom previous disease modifying antirheumatic drug treatment has failed. Ann Rheum Dis. 2004;63:508-516.

17. Breedveld FC, Weisman MH, Kavanaugh AF, et al; the PREMIER Investigators. The PREMIER study. A multicenter, randomized, double-blind clinical trial of combination therapy with adalimumab plus methotrexate versus methotrexate alone or adalimumab alone in patients with early, aggressive rheumatoid arthritis who had not had previous methotrexate treatment. Arthritis Rheum. 2006;54:26-37.

18. Bejarano V, Quinn M, Conaghan PG, et al; Yorkshire Early Arthritis Register Consortium. Effect of the early use of the anti-tumor necrosis factor adalimumab on the prevention of job loss in patients with early rheumatoid arthritis. Arthritis Rheum. 2008;59:1467-1474.

19. Weinblatt ME, Kremer JM, Bankhurst AD, et al. A trial of etanercept, a recombinant tumour necrosis factor receptor:Fc fusion protein in patients with rheumatoid arthritis receiving methotrexate. $N$ Engl $J$ Med. 1999;340:253-259.

20. Moreland LW, Schiff MH, Baumgartner SW, et al. Etanercept therapy in rheumatoid arthritis. A randomised, controlled trial. Ann Intern Med. 1999;130:478-486.

21. Klareskog L, van der Heidje D, de Jager JP, et al; for the TEMPO investigators. Therapeutic effect of the combination of etanercept and methotrexate compared with each treatment alone in patients with rheumatoid arthritis: double-blind randomised controlled trial. Lancet. 2004;363:675-681.

22. Emery P, Breedveld FC, Hall S, et al. Comparison of methotrexate monotherapy with a combination of methotrexate and etanercept in active, early, moderate to severe rheumatoid arthritis (COMET): a randomised, double-blind, parallel treatment trial. Lancet. 2008;372: 375-382.

23. Bathon JM, Martin RW, Fleischmann RM, et al. A comparison of etanercept and methotrexate in patients with early rheumatoid arthritis. New Engl J Med. 2000;343:1586-1593.

24. Keystone E, van der Heijde D, Mason D Jr, et al. Certolizumab pegol plus methotrexate is significantly more effective in active rheumatoid arthritis: findings of a fifty-two-week, phase III multicenter, randomised, double-blind, placebo-controlled, parallel-group study. Arthritis Rheum. 2009;58:3319-3329. Epub 2008 Oct 30.
25. Smolen JS, Landewé RBM, Mease PJ, et al. Efficacy and safety of certolizumab pegol plus methotrexate in active rheumatoid arthritis: the RAPID 2 study. Ann Rheum Dis. 2009 Jun;68:797-804. Epub 2008 Nov 17.

26. Fleischmann R, Vencovsky J, van Vollenhoven, et al. Efficacy and safety of certolizumab pegol monotherapy every 4 weeks in patients with rheumatoid arthritis failing previous disease-modifying antirheumatic therapy: the FAST4WARD study. Ann Rheum Dis. 2009 Jun;68:805-811. Epub 2008 Nov 17.

27. Keystone EC, Genovese MC, Klareskog L, et al. Golimumab, a human antibody to TNF $\alpha$ given by subcutaneous injections, active rheumatoid arthritis despite methotrexate: the GO-FORWARD study. Ann Rheum Dis. 2009;68:789-796.

28. Emery P, Fleischmann RM, Moreland LW, et al. Golimumab, a new human anti-TNF $\alpha$ monoclonal antibody, administered subcutaneously every 4 weeks in methotrexate-naive patients with active rheumatoid arthritis: a randomised, double-blind, placebo-controlled, GO-BEFORE study. Ann Rheum Dis. 2008;67 Suppl 2:S179.

29. Smolen JS, Kay J, Doyle MK, et al; the GO-AFTER study investigators. Golimumab in patients with active rheumatoid arthritis after treatment with tumour necrosis factor alpha inhibitors (GO-AFTER study): a multicentre, randomised, double-blind, placebo-controlled, phase III trial. Lancet. 2009;374:210-221.

30. Maini RN, Breedveld FC, Kalden JR, et al. Therapeutic efficacy of multiple intravenous infusions of anti-tumor necrosis factor $\alpha$ monoclonal antibody combined with low-dose weekly methotrexate in rheumatoid arthritis. Arthritis Rheum. 1998;41:1552-1563.

31. Maini RN, Breedveld FC, Kalden JR, et al. Sustained improvement over two years in physical function, structural damage, and signs and symptoms among patients with rheumatoid arthritis treated with infliximab and methotrexate. Arthritis Rheum. 2004;50:1051-1065.

32. Breedveld FC, Emery P, Keystone E, et al. Infliximab in active early rheumatoid arthritis. Ann Rheum Dis. 2004;63:149-155.

33. Quinn MA, Conaghan PG, O'Connor PJ, et al. Very early treatment with inflximab in addition to methotrexate in early, poor-prognosis rheumatoid arthritis reduces magnetic resonance imagng evidenc of synovitis and damage with sustained benefit after infliximab withdrawal. Arthritis Rheum. 2005;52:27-35.

34. Bejerano V, Conaghan P, Quinn M, Saleem B, Emery P. Benefits eight years after a remission induction regime with an infliximab and methotrexate combination in early rheumatoid arthritis. Rheumatology. Submitted 2010

35. Weinblatt ME, Keystone EC, Furst DE, Kavanaugh AF, Chartash EK, Segurado OG. Long term efficacy and safety of adalimumab plus methotrexate in patients with rheumatoid arthritis: ARMADA 4 year extended study. Ann Rheum Dis. 2006;65:753-759.

36. Keystone EC, Kavanaugh AF, Sharp JT, et al. Radiographic, clinical, and functional outcomes of treatment with adalimumab (a human anti-tumor necrosis factor monoclonal antibody) in patients with active rheumatoid arthritis receiving concomitant methotrexate therapy. A randomized, placebo-controlled, 52-week trial. Arthritis Rheum. 2004; 50:1400-1411.

37. Emery P, Genovese MC, van Vollenhoven R, Sharp JT, Patra K, Sasso EH. Less radiographic progression with adalimumab plus methotrexate versus methotrexate monotherapy across the spectrum of clinical response in early rheumatoid arthritis. J Rheumatol. 2009; 36:1429-1441.

38. Kimel M, Cifaldi M, Chen N, Revicki D. Adalimumab plus methotrexate improved SF-36 scores and reduced the effect of rheumatoid arthritis (RA) on work activity for patients with early RA. J Rheumatol. 2008;35: 206-215.

39. Van der Heijde D, Klareskog L, Singh A, et al. Patient reported outcomes in a trial of combination therapy with etanercept and methotrexate for rheumatoid arthritis: the TEMPO trial. Ann Rheum Dis. 2005;65: 328-334.

40. Emery P, Breedveld F, van der Heijde D, et al; Combination of Methotrexate and Etanercept in Early Rheumatoid Arthritis Trial Group. Two-year clinical and radiographic results with combination etanerceptmethotrexate therapy versus monotherapy in early rheumatoid arthritis. Arthritis Rheum. 2010;62:674-682. 
41. Genovese MC, Bathon JM, Martin RW, et al. Etanercept versus methotrexate in patients with early rheumatoid arthritis. Two-year radiographic and clinical outcomes. Arthritis Rheum. 2002;46:1443-1450.

42. Genovese MC, Bathon JM, Fleischmann RM, et al. Long-term safety, efficacy and radiographic outcome with etanercept treatment in patients with early rheumatoid arthritis. J Rheumatol. 2005;32:1232-1242.

43. Genant HK, Peterfy CG, Westhovens R, et al. Abatacept inhibits progression of structural damage in rhuematoid arthritis: results from the long-term extension of the AIM trial. Ann Rheum Dis. 2008;67: 1084-1089. Epub 2007 Dec 17.

44. Kremer JM, Geneant HK, Moreland LW, et al. Effects of abatacept in patients with methotrexate-resistant active rheumatoid arthritis: a randomised trial. Ann Intern Med. 2006;144:866-876.

45. Kremer JM, Dougados M, Emery P, et al. Treatement of rheumatoid arthritis with selective costimulation modulator abatacept. Arthritis Rheum. 2005;52:2263-2271.

46. Genovese MC, Becker JC, Schiff M, et al. Abatacept for rheumatoid arthritis refractory to tumour necrosis factor alpha inhibition. $N \mathrm{Engl}$ J Med. 2005;353:1114-1123.

47. Kremer JM, Geneant HK, Moreland LW, et al. Results of a two-year follow up study of patients with rheumatoid arthritis who received a combination of abatacept and methotrexate. Arthritis Rheum. 2008;58: 953-963.

48. Westhovens R, Kremer JM, Moreland LW, et al. Safetey and efficacy of the selective costimulation modulator abatacept in pateints with rheumatoid arthritis receiving background methotrexate: a 5-year extended phase IIB study. J Rheumatol. 2009;36:736-742.

49. Genovese MC, Schiff M, Luggen M, et al. Efficacy and safety of the selective co-stimulation modulator abatacept following 2 years of treatment in patients with rheumatoid arthritis and an inadequate response to anti-tumour necrosis factor therapy. Ann Rheum Dis. 2008;67:547-554.

50. Westhovens R, Robles M, Ximenes AC, et al. Clinical efficacy and safety of abatacept in methotrexate-naïve patients with early rheumatoid arthritis and poor prognostic factors. Ann Rheum Dis. Epub 2009 Jan 5.

51. Emery P, Durez P, Dougados M, et al. The impact of T-cell co-stimulation modulation in patients with undifferentiated inflammatory arthritis or very early rheumatoid arthritis: a clinical and imaging study of abatacept. Ann Rheum Dis. Epub 2009 Nov 23.

52. Arnett FC, Edworthy SM, Bloch DA, et al. The American Rheumatism Association 1987 revised criteria for the classification of rheumatoid arthritis. Arthritis Rheum. 1988;31:315-324.

53. Emery P, Fleischmann R, Filipowicz-Ssnowska A, et al; the DANCER study group. The efficacy and safety of rituximab in patients with active rheumatoid arthritis despite methotrexate treatment. Arthritis Rheum. 2006;54:1390-1400.

54. Furst DE, Breedvald FC, Kalden JR, et al. Updated consensus statement on biological agents for the treatment of rheumatic diseases, 2007. Ann Rheum Dis. 2007;66 Suppl 3:S2-S22.

55. Smolen JS, Keystone EC, Emery P, et al. Consensus statement on the use of rituximab in patients with rheumatoid arthritis. Ann Rheum Dis. 2007;66:143-150.

56. Dass S, Rawstron AC, Vital EM, Henshaw K, McGonagle D, Emery P. Highly sensitive B cell analysis predicts response to rituximab therapy in rheumatoid arthritis. Arthritis Rheum. 2008;58:2993-2999.

57. Vital EM, Dass S, Rawstron AC, et al. Management of non-response to rituximab in rheumatoid arthritis: predictors and outcome of retreatment. Arthritis Rheum. In press 2010.

58. Edwards JCW, Szczepański L, Szechiński J, et al. Efficacy of B-cell targeted therapy with rituximab in patients with rheumatoid arthritis. N Engl J Med. 2004;350:2572-2581.

59. Mease PJ, Revick DA, Szechinski J, et al. Improved health-related quality of life for patients with active rheumatoid arthritis receiving rituximab - results of the dose-ranging assessment: international clinical evaluation of rituximab in rheumatoid arthritis (DANCER) trial. J Rheumatol. 2008;35:20-30.
60. Cohen SB, Emery P, Greenwald MW, et al; the REFLEX trial group. Rituximab for rheumatoid arthritis refractory to anti-tumour necrosis factor therapy. Arthritis Rheum. 2006;54:2793-2806.

61. Muraguchi A, Hirano T, Tang B, et al. The essential role of B cell stimulatory factor 2 (BSF-2/IL-6) for the terminal differentiation of B cells. J Exp Med. 1988;167:332-344.

62. Lotz M, Jirik F, Kabouridis P, et al. B cell stimulating factor 2/interleukin 6 is a costimulant for human thymocytes and T lymphocytes. J Exp Med. 1989;557:417-435.

63. Maini RN, Taylor PC, Szechinski J, et al; for the CHARISMA study group. Double-blind randomised controlled clinical trial of the interleukin-6 receptor antagonist, tocilizumab, in European patients with rheumatoid arthritis who had an incomplete response to methotrexate. Arthritis Rheum. 2006;54:2817-2829.

64. Smolen JS, Bealieu A, Rubbert-Roth A, et al; for the OPTION investigators. Effect of interleukin-6 receptor inhibition with tocilizumab in patients with rheumatoid arthritis (OPTION study): a double-blind, placebo-controlled, randomised trial. Lancet. 2008;371: 987-997.

65. Genovese MC, McKay JD, Nasonev EL, et al. Interleukin-6 receptor inhibition with tocilizumab reduces disease activity in rheumatoid arthritis with inadequate response to disease-modifying antirheumatic drugs. Arthritis Rheum. 2008;58:2968-2980.

66. Emery P, Keystone E, Tony HP, et al. Il-6 receptor inhibition with tocilizumab improves treatment outcomes in patients with rheumatoid arthritis refractory to anti-tumour necrosis factor biologicals: results from a 24-week multicentre randomised placebo-controlled trial. Ann Rheum Dis. 2008;67:1516-1523. Epub 2008 Jul 14.

67. Nishimoto N, Hashimoto J, Miyasaka N, et al. Study of active controlled monotherapy used for rheumatoid arthritis an IL-6 inhibitor (SAMURAI): evidence of clinical and radiographic benefit from an $\mathrm{X}$ ray reader-blinded randomised controlled trial of tocilizumab. Ann Rheum Dis. 2007;66:1162-1167. Epub 2007 May 7.

68. Kremer J, Fleischmann RM, Saurigny D, Alecock E, Blanco R. Safety and tolerability of tocilizumab in combination with methotrexate (MTX) in patients with rheumatoid arthritis and inadequate response to MTX: 1-year results of the LITHE study. Ann Rheum Dis. 2009;68 Suppl 3:444.

69. Jones G, Sebba A, Gu J, et al. Comparison of tocilizumab monotherapy versus methotrexate monotherapy in patients with moderate to severe rheumatoid arthritis: the AMBITION study. Ann Rheum Dis. Epub 2009 March 17.

70. Smolen JS, Alten RHE, Gomez-Reino J, et al. Efficacy of tocilizumab in rheumatoid arthritis: interim analysis of long-term extension trials of up to 2.5 years. Ann Rheum Dis. 2009;68 Suppl 3:401.

71. Furst DE, Schiff MH, Fleischmann RM, et al. Adalimumab, a fully human anti-tumour necrosis factor- $\alpha$ monoclonal antibody, and concomitant standard antirheumatic therapy for the treatment of rheumatoid arthritis: results of STAR (safety trial of adalimumab in rheumatoid arthritis). J Rheumatol. 2003;30:12.

72. Bongartz T, Sutton AJ, Sweeting MJ, Buchan I, Matteson EL, Montori V. Anti-TNF antibody therapy in rheumatoid arthritis and the risk of serious infections and malignancies. JAMA. 2006;295:2275-2285.

73. Salliot C, Gossec L, Ruyssen-Witrand A, et al. Infections during tumour necrosis factor- $\alpha$ blocker therapy for rheumatic diseases in daily practice: a systematic retrospective study of 709 patients. Rheumatology. 2007;46:327-334.

74. Dixon WG, Symmons DPM, Lunt M, Watson KD, Hyrich KL, Silman AJ. British Society for Rheumatology Biologics Register Control Centre Consortium. Serious infection following anti-tumor necrosis factor- $\alpha$ therapy in patients with rheumatoid arthritis: Lessons from interpreting data from observational studies. Arthritis Rheum. 2007;56:2896-2904.

75. Van Vollenhoven RF, Emery P, Bingham CO, et al. Long-term safety of rituximab: follow-up of the RA clinical trials and the re-treatment population. Ann Rheum Dis. 2009;68 Suppl 3:76. 
76. Dixon WG, Hyrich KL, Watson KD, et al. Drug-specific risk of tuberculosis in patients with rheumatoid arthritis treated with anti-TNF therapy: results from the British Society for Rheumatology Biologics Register (BSRBR). Ann Rheum Dis. Epub 2009 Oct 22.

77. Furst DE, Wallis R, Broder M, Beenhouwer DO. Tumor necrosis factor antagonists: different kinetics and/or mechanisms of action may explain differences in the risk for developing granulomatous infection. Sem Arth Rheum. 2006;36:159-167.

78. Carmona L, Gómez-Reino JJ, Rodríguez-Valverde V, et al; BIOBADASER Group. Effectiveness of recommendations to prevent reactivation of latent tuberculosis infection in patients treated with tumor necrosis factor antagonists. Arthritis Rheum. 2005;52:1766-1772.

79. Desai SB, Furst DE. Problems encountered during anti-tumour necrosis factor therapy. Bes Pract Res Clin Rheum. 2006;20:757-790.

80. Peterson JR, Hsu FC, Simkin PA, Wener MH. Effect of tumour necrosis factor alpha antagonists on serum transaminases and viremia in patients with rheumatoid arthritis and chronic hepatitis C infection. Ann Rheum Dis. 2003;62:1078-1082.

81. Zein NN; Etanercept Study Group. Etanercept as an adjuvant to interferon and ribavirin in treatment-naïve patients with chronic hepatitis $\mathrm{C}$ virus infection: a phase 2 randomized, double-blind, placebocontrolled study. J Hepatol. 2005;42:315-322.

82. Amari W, Zeringue AL, McDonald JR, et al. Non-melanoma and melanoma skin cancer risk in a national cohort of veterans with rheumatoid arthritis. ACR 2008, Abstract 1379. Available from: http:// acr.confex.com/acr/2009/webprogram/Paper11467.html

83. Askling J, Fored CM, Brandt L, et al. Risks of solid cancers in patients with rheumatoid arthritis and after treatment with tumour necrosis factor antagonists. Ann Rheum Dis. 2005;64:1421-1426.

84. Dixon W, Watson KD, Lunt M, et al. The influence of anti-TNF therapy upon cancer incidence in patients with rheumatoid arthritis (RA) who have had prior malignancy: results from the BSRBR. Arthritis Rheum. 2008;58 Suppl:S638-S639.
85. Mariette X, Tubach F, Ravaud P, et al. Patients on anti-TNF have an increased risk of lymphoma compared with the general population: results of the French RATIO observatory. Ann Rheum Dis. 2008;67 Suppl 2:323.

86. Askling J, Fored CM, Baecklund E, et al. Hematopoietic malignancies in rheumatoid arthritis: lymphoma risk and characteristics after exposure to tumour necrosis factor antagonists. Ann Rheum Dis. 2005;64: 1414-1420.

87. Westhovens R, Yocum D, Han J, et al; START Study Group. The safety of infliximab, combined with background treatments, among patients with rheumatoid arthritis and various comorbidities: a large, randomized, placebo-controlled trial. Arthritis Rheum. 2006;54:1075-1086.

88. Harrison MJ, Dixon WG, Watson KD, et al. Rates of new-onset psoriasis in patients with rheumatoid arthritis receiving anti-TNF $\alpha$ therapy: results from the British Society for Rheumatology Biologics Register. Ann Rheum Dis. 2009;68:209-215.

89. Carson KR, Evens AM, Richey EA, et al. Progressive multifocal leukoencephalopathy after rituximab therapy in HIV-negative patients: a report of 57 cases from the Research on Adverse Drug Events and Reports project. Blood. 2009;113:4834-4840. Epub 2009 March 5.

90. Mann D, McMurray J, Packer M, et al. Targeted anticytokine therapy in patients with chronic heart failue: results of the randomised etanercept worldwide evaluation (RENEWAL). Circulation. 2004;109: 1594-1602.

91. Hyrich KL, Symmons DPM, Watson KD, Silman AJ. Pregnancy outcome in women who were exposed to anti-tumor necrosis factor agents: results from a national population register. Arthritis Rheum. 2006;54:2701-2702

92. Hyrich KL, Lunt M, Watson KD, Symmons DP, Silman AJ. Outcomes after switching from one anti-tumour ncrosis factor alpha agent to a second anti-tumour necrosis factor agent in patients with rheumatoid arthritis: results from a large UK national cohort study. Arthritis Rheum 2007;66:893-899.

93. Ikeda K, Cox S, Emery P. Biological therapy in early arthritis overtreatment or the way to go? Arthritis Res Ther. 2007;9:211-217.
Drug, Healthcare and Patient Safety

\section{Publish your work in this journal}

Drug, Healthcare and Patient Safety is an international, peer-reviewed open-access journal exploring patient safety issues in the healthcare continuum from diagnostic and screening interventions through to treatment, drug therapy and surgery. The journal is characterized by the rapid reporting of reviews, original research, clinical, epidemiological and

\section{Dovepress}

post-marketing surveillance studies, risk management, health literacy and educational programs across all areas of healthcare delivery. The manuscript management system is completely online and includes a very quick and fair peer-review system. Visit http://www.dovepress.com/ testimonials.php to read real quotes from published authors. 